\title{
Synthesis and Biological Activity of a New Pt(II) Complex Involving 4-bromo-2,6-bis-hydroxymethyl- phenol and Nicotinamide
}

Özlen Altun ( $\sim$ ozlenaltun@yahoo.com )

Trakya University: Trakya Universitesi

Zeliha Yoruç

Trakya University: Trakya Universitesi

Mesut Boz

Trakya University: Trakya Universitesi

\section{Research Article}

Keywords: Platinum(II), Bioactive compounds, Structural analysis, Bioactivity

Posted Date: August 13th, 2021

DOI: https://doi.org/10.21203/rs.3.rs-774963/v1

License: (c) (i) This work is licensed under a Creative Commons Attribution 4.0 International License.

Read Full License 


\section{Abstract}

In the presented study, Pt(II) complex including 4-Bromo-2,6-bis-hydroxymethyl-phenol (BBHMP) and nicotinamide (NA) was synthesized and structurally analyzed by using spectral and thermal analysis methods. The BBHMP and its Pt(II) complex involving BBHMP and NA were investigated for their antimicrobial, cytotoxicity, gen expression and antioxidant properties. The antimicrobial activity results showed that the platinum complex displayed moderate antibacterial and antifungal activities. The cytotoxicity of the BBHMP and platinum complex were determined against human prostate (DU145) and breast (MCF7) cancer cell lines by applying MTT assay. Cytotoxicity results suggest that the Pt(II) complex exhibited moderate cytotoxicity against growth of used cancer cell lines when compared with the reference drug cisplatin. Gen expression results proved that $\mathrm{Pt}(\mathrm{II})$ complex is a special bioactive chemical constituent and potential anticancer agent. In addition, the complex demonstrated important antioxidant activity.

\section{Introduction}

Multidentate ligands can easily form stable complexes with most transition metal ions [1-3]. These complexes have potential applications in inorganic, biological, medicinal and environmental chemistry. 4Bromo-2,6-bis-hydroxymethyl-phenol (BBHMP) is a chemosensor for $\mathrm{F}^{-}$ions in aqueous media [4] and a colorimetric method for the detection of $\mathrm{F}$ with BBHMP has been described [5]. BBHMP, a multidentate ligand [6, 7], is a halogenated phenol derivative that is obtained from 4-bromophenol, formaldehyde and sodium hydroxide and used for proteomic research. It has three oxygen atoms that can be coordinated to metal ions to form metal complexes [8-10]. In the previous studies, copper(II) [8], palladium(II) [9]. and gold(III) [10] complexes were synthesized using BBHMP and characterized with various spectrophotometric techniques and also determined the thermodynamic parameters. In these studies, they were found to be active against Staphylococcus faecalis and Escherichia coli when their biological applications were investigated.

Nicotinamide (pyridine-3-carboxamide, NA) is a significant consistituent of hydrogen-carrying co-enzymes such as nicotinamide-adenine dinucleotide. NA is a form of vitamin B3 found in food and it plays a vital role for the metabolism of all living cells. It is used to treat acne as a cream, orally to prevent and treat pellagra. The presence of the pyridine ring, which is inherent in numerous compounds of nicotinamides, is also of interest. Nicotinamide has been used in many studies due to its chemical structure. Nicotinamide is a biologically active reagent which has significant antimicrobial, cytotoxicity and anticancer activities [11-13]. So far, many studies have been reported on the synthesis and biological properties of metal-based nicotinamide compounds [14-17]. For example, Dilip et al. [15] studied synthesis, spectral analysis, biological and DNA cleavage properties of various transition metal complexes of nicotinamide. In another study by Tella et al. [16], Ni(II) nicotinamide complexes involving fumarate dianion and fumaric acid were synthesized to reveal their biological activites. Structurally, nicotinamide contains an aromatic ring and only the $\mathrm{N} 1$ atom interacts with the metal cation [17-20]. The chemical structures of BBHMP and NA are below: 
Up to now, no references to the biological activity of Pt(II) complex involving a multidentate ligand BBHMP and NA has been reported. Therefore, it is important to examine the biological activity behaviors that playing an important role in various chemical and biological fields. For these reasons, in the presented study, the platinum(II) complex of BBHMP and NA was synthesized. The complex was characterisized by using spectral and termal analysis methods. The BBHMP and Pt(II) complex were evaluated for antimicrobial activities against $E$. coli, S. typhimurium, L. monocytogenes, S. aureus, $B$. cereus and $C$. albicans. The ampicillin and amphotericin $B$ were used as antibiotics and the obtained results were compared with these antibiotics. The BBHMP and platinum(II) complex were also examined for cytotoxicity (with cisplatin used as comparison) and gen expression against human prostate (DU145) and human breast (MCF7) cancer cell lines. In addition, antioxidant activity of the BBHMP, NA and complex were determined.

\section{Experimental Section}

\section{Material and measurements}

All chemicals were purchased from various firms and they were used as supplied. Elemental analysis for carbon, hydrogen, oxygen and nitrogen were measured by a Costech ECS 4010 CHNSO element analyzer and an ICP-MS 7700X (Agilent) element analyzer was used for platinum. Conductivity analysis were calculated by an Inolab Thermal 740P in DMF. The magnetic moment experiments were obtained with a MK-1 Sherwood scientific magnetic susceptibility balance. Electrospray ionization mass spectra (ESI-MS) were determined on an Agilent 6400 Series Triple Quadrupole. Electronic spectra in the UV-Visible region were observed by using a Shimadzu UV-1700 Pharma spectrophotometer at room temperature. A Shimadzu FTIR-470 spectrometer was used for recording infrared spectra $\left(4000-400 \mathrm{~cm}^{-1}\right)$ of solid samples in $\mathrm{KBr}$ pellets. ${ }^{1} \mathrm{H}$ NMR spectra were performed in $\mathrm{CDCl}_{3}$ for the complex on a Bruker, DPX-400 spectrometer. The TG/DTA curves were created on a Seiko Exstar TG/DTA 6200 thermal analyzer at a temperature range of $25-1000{ }^{\circ} \mathrm{C}$.

\section{The synthesis of Pt(II) complex}

Amounts of $0.116 \mathrm{~g} \mathrm{(1} \mathrm{mmol})$ BBHMP, $0.06 \mathrm{~g} \mathrm{(3} \mathrm{mmol)} \mathrm{NaOH}$ and $0.121 \mathrm{~g} \mathrm{(2} \mathrm{mmol})$ NA were dissolved in $25 \mathrm{~mL}$ ethanol. An equivalent amount of solution of $0.83 \mathrm{~g}(2 \mathrm{mmol}) \mathrm{K}_{2} \mathrm{PtCl}_{4}$ was added and heated for 3 hours at $\sim 80^{\circ} \mathrm{C}$ under reflux conditions. A brown solid precipitate which dissolved in organic solvents such as DMF, DMSO and $\mathrm{CHCl}_{3}$ was obtained.

[Pt $\left.{ }_{2}(\mathrm{BBHMP})(\mathrm{NA})_{2} \mathrm{Cl}\right]$ or $\left[\mathrm{Pt}_{2}\left(\mathrm{C}_{8} \mathrm{H}_{6} \mathrm{O}_{3} \mathrm{Br}\right)\left(\mathrm{C}_{6} \mathrm{H}_{6} \mathrm{~N}_{2} \mathrm{O}\right){ }_{2} \mathrm{Cll}\right.$ : Yield (\%): 78. Color: Brown. MP. ( $\left.{ }^{\circ} \mathrm{C}\right): 203$. Elemental Analysis (\%): Calcd.: C 26.68, H 2.0, 0 8.89, N 6.22, Pt: 43.37; Found: C 26.64, H 2.02, $\mathrm{O}$ 8.83, N

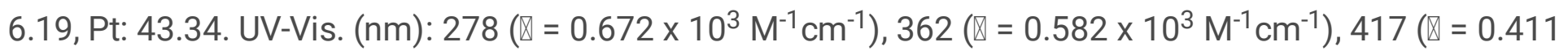
$\left.\times 10^{3} \mathrm{M}^{-1} \mathrm{~cm}^{-1}\right)$. FTIR $\left(\mathrm{cm}^{-1}\right): 3352 \mathrm{v}\left(\mathrm{NH}_{2}\right), 1698 \mathrm{v}(\mathrm{C}=\mathrm{O}), 1621 \mathrm{v}(\mathrm{C}=\mathrm{N}), 1525 \mathrm{v}(\mathrm{C}=\mathrm{C}), 1278 \mathrm{v}(\mathrm{C}-\mathrm{N}), 1231$ v(NHdef), $673 \mathrm{v}(\mathrm{Pt}-\mathrm{O}), 585 \mathrm{v}(\mathrm{Pt}-\mathrm{N}) .{ }^{1} \mathrm{H}$ NMR $\left(300 \mathrm{MHz}, \mathrm{CDCl}_{3}\right) \delta: 6.72\left(\mathrm{~s}, 2 \mathrm{H}, \mathrm{C}_{2}-\mathrm{H}\right.$ and $\left.\mathrm{C}_{6}-\mathrm{H}\right), 9.12(\mathrm{~s}, 2 \mathrm{H}$, 
$\left.\mathrm{C}_{2}-\mathrm{H}\right), 8.36\left(\mathrm{~m}, 4 \mathrm{H}, \mathrm{C}_{4}-\mathrm{H}\right.$ and $\left.\mathrm{C}_{5}-\mathrm{H}\right), 8.68\left(\mathrm{~d}, \mathrm{~J}=6 \mathrm{~Hz}, 2 \mathrm{H}, \mathrm{C}_{6}-\mathrm{H}\right), 4.37\left(\mathrm{~s}, 4 \mathrm{H}, \mathrm{C}_{7}-2 \mathrm{H}\right.$ and $\left.\mathrm{C}_{8}-2 \mathrm{H}\right), 7.49-7.55(\mathrm{~m}$, $\left.4 \mathrm{H}, \mathrm{NH}_{2}\right)$. Conductivity $\left(\Omega^{-1} \mathrm{~cm}^{2} \mathrm{~mol}^{-1}\right)$ : 17.92. ESI-MS $(\mathrm{m} / \mathrm{z})$ : For $\left[\mathrm{M}_{\mathrm{BBHMP}}\right]^{+}$, calcd.: 229.97, found: 230; for $\left[\mathrm{M}_{\mathrm{NA}}+\mathrm{H}\right]^{+}$, calcd.: 122.98 , found: 122 and for $[\mathrm{M}]^{+}$, calcd.: 899.62 , found: 899.66 . According to the following synthesis reaction:

\section{Antimicrobial activity}

The antimicrobial activities of the BBHMP and platinum complex were tested against gram(-) Escherichia coli $\left(\right.$ ATCC® $\left.25922^{\mathrm{Tm}}\right)$, Salmonella typhimurium (ATCC® $14028^{\mathrm{TM}}$ ), Listeria monocytogenes (ATCC® $19115^{\mathrm{TM}}$ ) gram (+) Staphylococcus aureus (ATCC $\left.\cap 25923^{\mathrm{TM}}\right)$, Bacillus cereus $\left(\right.$ ATCC $\left.B 11778^{\mathrm{TM}}\right)$, and fungal Candida albicans $\left(A T C C{ }^{\circledR} 1023^{\mathrm{TM}}\right)$. The micro broth dilution method and Clinical and Laboratory Standards Institute (CLSI) [21-25] procedures were used to find the minimal inhibition concentration values (MIC). To measure the area for zone of inhibition, Ampicillin for bacterial strains and Amphotericin $B$ for fungal strains were chosen as antibiotic (positive control). DMSO, which has no activity, was used as negative control. The testing micro-organisms were prepared in the concentration range 200 and 6.25 $\mu \mathrm{g} / \mathrm{mL}$ and added into a sterile 96 -well microplate. Then, the microplate kept in incubation for growth of testing micro-organisms for 24 hours at $37^{\circ} \mathrm{C}$. After incubation, the absorbance was recorded at $600 \mathrm{~nm}$ using a Thermo Multiscan GO Microplate Reader Spectrophotometer. Any color change from purple to pink determined visually was recorded as positive. The lowest concentration with a color change was considered as the MIC value. Experiments were conducted four times.

\section{Cell culture}

Human prostate (DU145, ATCC $®$ HTB-81 $1^{\mathrm{TM}}$ ) and breast (MCF7-ATCC $® \mathrm{HTB}-22^{\mathrm{TM}}$ ) cancer cells were cultured in Dulbecco's Modified Eagle Medium (DMEM) : F-12 medium and 10\% foetal bovine serum (FBS, Gibco $^{\text {TM }}$ 10270106), $2 \mathrm{mM}$ glutamine (Multicell, USA) and $100 \mathrm{lU} / \mathrm{mL}$ penicillin-streptomycin (Invitrogen, Life Technologies). Cells were stored in a humidified incubator at $37^{\circ} \mathrm{C}$ and $5 \% \mathrm{CO}_{2}$.

\section{MTT analysis for cytotoxicity}

The cytotoxicity was determined by MTT assay [25-28]. The MTT method is a widely used cell viability test for cytotoxicity and can be used with all cancer cell types because it metabolizes all living cells. In this method, both DU145 and MCF7 cancer cell lines were added in a sterile 96 -well microplate by using a culture medium ( 7500 cells/well in $200 \mu \mathrm{L}$ ) for 24 hours. A hemocytometer with trypan blue dye was used to determine cell viability and $95 \%$ of the cell viability was confirmed. For connecting cells to wells, the microplate was incubated in a $5 \% \mathrm{CO}_{2}$ incubator for 24 hours at $37^{\circ} \mathrm{C}$. Then, the BBHMP or platinum(II) complex prepared at the concentrations of $25,50,100,200,400$ and $800 \mu \mathrm{M}$ was transferred to the wells and incubated for 24 hours. After 24 hours, $20 \mu \mathrm{L} / 200 \mu \mathrm{L}$ per well was transferred from $5 \mathrm{mg} / \mathrm{mL}$ MTT (3- (4,5-dimethyl-thiazol-2-yl) -2,5-diphenyltetrazolium bromide) solution and kept in incubation at $37^{\circ} \mathrm{C}$ for an additional 4 hours. During incubation, MTT is converted to a colored formazan salt that is insoluble in water by the metabolic activity of living cells. The formazan blue occurred in the cell lines 
was dissolved in DMSO (200 $\mu \mathrm{L} /$ well). A Thermo Multiskan GO Microplate Reader Spectrophotometer $(492 \mathrm{~nm})$ was used to measure the optical density. The measured absorbance value for each concentration of BBHMP or platinum complex was compared with the DMSO-treated control. All experiments were repeated six times. The percentage growth inhibition was found with the following formula [29]:

$$
\text { Growth inhibition } \%=\frac{\text { OD control }- \text { OD treated sample }}{\text { OD control }} \times 100
$$

$\mathrm{IC}_{50}$ levels was obtained by probit analysis using SPSS 20 software and compared with the reference drug cisplatin. As a result of the probit analysis, it was determined that there were sufficient $I C_{50}$ values in the BBHMP and Pt(II) complex for anticancer activity. Therefore, gene expression analysis of BBHMP and $\mathrm{Pt}(\mathrm{II})$ complex for anticancer activity were performed.

\section{Gene expression analysis}

Total RNA was isolated from three wells of six cell culture well plates from each groups which was $\mathrm{IC}_{50}$ dose of BBHMP or Pt(II) complex treated and vehicle treated control by the PureLink® RNA mini kit (Life Technologies, USA) according to the manufacturer's instructions. The Qubit ${ }^{\circledR}$ Fluorometer (Thermo Scientific, USA) was used to record extracted RNA concentrations. The total RNA concentration was adjusted to $100 \mathrm{ng} / \mu \mathrm{L}$ with a high capacity complementary DNA (CDNA) reverse transcription kit (Life Technologies, USA) for the synthesis of the first strand of cDNA. CDNA synthesis was realized with the thermal cycler Applied Biosystems ${ }^{\circledR}$ Veriti ${ }^{\circledR}$ (Thermo Scientific, USA) at the three steps which were Step 1: $25^{\circ} \mathrm{C}, 10 \mathrm{~min}$; Step 2: $37^{\circ} \mathrm{C}, 120 \mathrm{~min}$; Step 3: $85^{\circ} \mathrm{C}, 5 \mathrm{~min}$, respectively. The synthesized cDNA was kept at $-20^{\circ} \mathrm{C}$ for later analysis steps $[25,28,30-33]$. Expression levels of the mitochondrial apoptosis genes in both cancer cells of vehicle treated control and $\mathrm{IC}_{50}$ doses treated with BBHMP or Pt(II) complex for 24 hours were determined with quantitative real-time-polymerase chain reaction (qRT-PCR) by using the PowerSYBR® Select Master Mix (Life Technologies, USA) by an ABI 7500 Real-Time PCR system (Thermo Scientific, USA). Genes, primer sequences and PCR conditions were presented in Table 1. The gene expressions were found as relative fold change compared to vehicle control treated and normalized with glyceraldehyde-3-phosphate dehydrogenase messenger RNA (GAPDH mRNA) expressions. The expressions levels of mRNAs were examined by using the comparative cycle threshold (2- $\Delta \Delta \mathrm{Ct})$ method (User Bulletin 2, Applied Biosystems, CA). All experiments were made four times. 
Table 1

Genes, primer sequences and PCR conditions belong to qRT-PCR

\begin{tabular}{|c|c|c|}
\hline & Mithocondrial apoptosis signaling & \\
\hline Genes & Primer sequences & PCR conditions \\
\hline P53 F 5' & CACGAGCGCTGCTCAGATAGC 3' & 1 cycle of $2 \mathrm{~min}$ at $50^{\circ} \mathrm{C}$ \\
\hline R $5^{\prime}$ & ACAGGCACAAACACGCACAAA 3' & and $10 \mathrm{~min}$ at $95^{\circ} \mathrm{C}$ for $15 \mathrm{~s}$, \\
\hline BCL2 F 5' & ATGTGTGTGGAGAGCGTCAA 3' & annealing and extension \\
\hline R $5^{\prime}$ & ACAGTTCCACAAAGGCATCC 3' & at $60^{\circ} \mathrm{C}$ for $1 \mathrm{~min}$ \\
\hline BAX F 5' & TTCATCCAGGATCGAGCAGA 3' & \\
\hline R $5^{\prime}$ & GCAAAGTAGAAGGCAACG 3' & \\
\hline APAF1 F 5' & GATATGGAATGTCTCAGATGGCC 3' & \\
\hline R $5^{\prime}$ & GGTCTGTGAGGACTCCCCA 3' & \\
\hline Cyt-C F 5' & AGTGGCTAGAGTGGTCATTCATTTACA 3' & \\
\hline R $5^{\prime}$ & TCATGATCTGAATTCTGGTGTATGAGA 3' & \\
\hline Caspase 3 F 5' & GGTATTGAGACAGACAGTGG 3' & \\
\hline R $5^{\prime}$ & CATGGGATCTGTTTCTTTGC 3' & \\
\hline GADPH F 5' & TTGGTATCGTGGAAGGACTCA 3' & \\
\hline R $5^{\prime}$ & TGTCATCATATTTGGCAGGTTT 3' & \\
\hline
\end{tabular}

\section{Antioxidant activity}

Antioxidants are free radical scavengers and the DPPH (2,2-Diphenyl-1-picrylhydrazyl) assay is a simple and rapid method widely used to determine the free radical scavenging capacity of different antioxidants $[25,34-36]$. The radical in DPPH gives a purple color with maximum absorption at $517 \mathrm{~nm}$. When the radical reacts with an antioxidant, the absorbance of DPPH decreases and the color disappears [37]. In this study, different concentrations of the BBHMP, NA and platinum(II) complex was prepared by serial dilution in $\mathrm{CHCl}_{3}$ at a concentration range of 0.5 to $2 \mu \mathrm{g} / \mathrm{ml}$. The reaction medium composition was DPPH radical $(0.5 \mu \mathrm{g} / \mathrm{mL}, 100 \mu \mathrm{L})$ and test components dissolved in $100 \mu \mathrm{L} \mathrm{CHCl}_{3}$. BHT (2,6-di-tert-butyl4-methylphenol) in $\mathrm{MeOH}$ at a concentration range of $0.5-2 \mu \mathrm{g} / \mathrm{mL}$ was used as a positive control. $\mathrm{CHCl}_{3}$ and $\mathrm{MeOH}$ were chosen for the blanks. It was then incubated in the dark for 1 hour, and the $\mathrm{IC}_{50}(50 \%$ inhibition of DPPH color) values were calculated by mesuring the absorbance against a blank at $517 \mathrm{~nm}$ with a Tecan-PC endless M200 Pro Plate reader. Experiments were performed in duplicate. Antioxidant Activity \% was found by the following formula: 
Antioxidant $\%=\frac{\text { Ablank }- \text { Asample }}{\text { Ablank }} \times 100$

where Ablank is the absorbance of the blank and Asample is the absorbance of sample.

\section{Result And Discussion \\ Structural analysis}

Elemental analysis of $\mathrm{C}, \mathrm{H}, \mathrm{O}, \mathrm{N}$ and $\mathrm{Pt}$ is in compliance with the proposed molecular formula complex. The molar conductance of the platinum(II) complex can be found by using the formula [38]:

$$
\Lambda \mathrm{m}=\frac{\mathrm{K}}{\mathrm{C}}
$$

where $\mathrm{C}$ is the molar concentration and $\mathrm{K}$ is specific conductance. For the molar conductance, the complex was dissolved in $1 \times 10^{-3} \mathrm{M} \mathrm{DMF}$ solvent at room temperature. It was measured and found to have a molar conductance value of $17.92 \mathrm{ohm}^{-1} \mathrm{~mol}^{-1} \mathrm{~cm}^{2}$. As a result, the obtained complex is a nonelectrolyte complex $[39,40]$. According to the magnetic moment measurement, as expected in low spin platinum(II) complexes, the synthesized Pt(II) complex is diamagnetic and has a square planar geometry.

ESI-MS (Electrospray ionization mass spectrometry) was recorded to specify molecular weight and fragments of the complex. In the ESI-MS spectra of the platinum complex (Fig. 1), the peaks at $m / z=$ 229.97 (found: 230 ) and 122.98 (found: 122) were compatible with $\left[\mathrm{M}_{\mathrm{BBHMP}}\right]^{+}$and $\left[\mathrm{M}_{\mathrm{NA}}\right]^{+}$, respectively. The peak at $m / z=899.62$ (found: 899.66 ) corresponds to molecular weight ([M] ${ }^{+}$) of the molecular formula of the complex among several molecular weights recorded based on the isotope distribution of platinum. In addition, The spectrum shows isotope peaks at $m / z 654$ and 656 , which correspond to the cation resulting from the removal of NA molecules from the complex.

In the electronic spectra of the $\mathrm{Pt}(\mathrm{II})$ complex in $\mathrm{CHCl}_{3}$ between 200 and $450 \mathrm{~nm}$, there is a wide range of band resulting from both $\pi-\pi^{*}(-C=N,-C=0)$ and $n-\pi^{*}$ transitions (the long pair electrons on the $O$ and $N$ atoms). The complex exhibits three absorption bands in the range $417\left(\mathbb{\nabla}=411 \mathrm{I} \mathrm{mol}^{-1} \mathrm{~cm}^{-1}\right), 362(\mathbb{\nabla}=$ $\left.582 \mathrm{I} \mathrm{mol}^{-1} \mathrm{~cm}^{-1}\right)$ and $278 \mathrm{~nm}\left(\mathbb{\nabla}=672 \mathrm{I} \mathrm{mol}^{-1} \mathrm{~cm}^{-1}\right)$ which are attributed to ${ }^{1} \mathrm{~A}_{1 \mathrm{~g}} \rightarrow{ }^{1} \mathrm{~A}_{2 \mathrm{~g}},{ }^{1} \mathrm{~A}_{1 \mathrm{~g}} \rightarrow{ }^{1} \mathrm{~B}_{1 \mathrm{~g}}$ and ${ }^{1} A_{1 g} \rightarrow{ }^{1} E_{g}$ transitions, respectively. These results indicate that the synthesized platinum complex has a low spin square-planar coordination of the central $\mathrm{Pt}^{2+}$ ion by the surrounding BBHMP and NA [4144].

The FTIR spectra of the BBHMP, NA [45-47] and Pt(II) complex complex are given in Table 2. The v( $\left.\mathrm{NH}_{2}\right)$ stretching vibration seen at $3351 \mathrm{~cm}^{-1}$ in the free NA is also seen at $3352 \mathrm{~cm}^{-1}$ in the complex. According to this result, there is no significant shift in the spectrum of the complex, which indicates that 
the $\mathrm{NH}_{2}$ group is not involved in coordination. The band observed at $1231 \mathrm{~cm}-1$ also supports that there is no coordination at this point due to the $\mathrm{N}-\mathrm{H}$ deformation vibration position in metal complexes [48]. The $v(C=N)$ and $v(C-N)$ vibrations which occur at 1612 and $1255 \mathrm{~cm}^{-1}$ in the NA are shifted in the complex due to coordination via the $N$ of the pyridine ring [49]. The vibrations of $v(C=0)$ and $v(C=C)$ at 1680 and $1542 \mathrm{~cm}^{-1}$ in the free NA shift to higher frequencies in the complex. The $\mathrm{Pt}^{2+}$ bonded oxygen atoms in the BBHMP structure attract electrons from neighboring atoms, making the bonds between neighboring atoms more polar. Therefore, functional groups occur at higher wave numbers. In the FTIR spectra of the complex, in the presence of peaks at 673 and $585 \mathrm{~cm}^{-1}$ which may be attributed to $\mathrm{v}$ (Pt-0) and $\mathrm{v}(\mathrm{Pt}-\mathrm{N})$ confirms coordination by the oxygen and nitrogen atoms in the $\mathrm{v}(\mathrm{C}-\mathrm{O})$ and $\mathrm{v}(\mathrm{C}-\mathrm{N})$ groups, respectively [50].

Table 2

Characteristic FTIR values $\left(\mathrm{cm}^{-1}\right)$ of the BBHMP, NA and Pt(II) complex

\begin{tabular}{|lllllllll|}
\hline Compound & $\mathbf{v}\left(\mathrm{NH}_{2}\right)$ & $\mathbf{v}(\mathrm{C}=\mathbf{0})$ & $\mathbf{v}(\mathrm{C}=\mathrm{N})$ & $\mathbf{v}(\mathrm{C}=\mathrm{C})$ & $\mathbf{v}(\mathrm{C}-\mathrm{N})$ & $\mathbf{v}(\mathrm{NHdef})$ & $\mathbf{v}(\mathrm{PtO})$ & $\mathbf{v}(\mathrm{PtN})$ \\
\hline BBHMP & - & - & - & 1618 & - & - & - & - \\
NA & 3351 & 1680 & 1612 & 1542 & 1255 & 1163 & - & - \\
Complex & 3352 & 1698 & 1621 & 1525 & 1278 & 1231 & 673 & 585 \\
\hline
\end{tabular}

${ }^{1} \mathrm{H}$ NMR $\left(300 \mathrm{MHz}, \mathrm{CDCl}_{3}\right.$ ) spectra of BBHMP, NA and their Pt(II) complex support the coordination of $\mathrm{Pt}^{2+}$ ion with BBHMP and NA molecules. According to ${ }^{1} \mathrm{H}$ NMR results, of BBHMP, the characteristic ${ }^{1} \mathrm{H} N M R$ signals at $\delta=4.62$ and $5.8 \mathrm{ppm}$ are assigned to aliphatic $\mathrm{CH}_{2}\left(\mathrm{~s}, 1 \mathrm{H}, \mathrm{C}_{7}-\mathrm{H}\right.$ and s, $\left.1 \mathrm{H}, \mathrm{C}_{8}-\mathrm{H}\right)$ and $\mathrm{OH}(\mathrm{s}, 1 \mathrm{H}$, $\mathrm{OH})$ protons, respectively. The peak at $\delta=7.41 \mathrm{ppm}\left(\mathrm{s}, 1 \mathrm{H}, \mathrm{C}_{2}-\mathrm{H}\right.$ and s, $\left.1 \mathrm{H}, \mathrm{C}_{6}-\mathrm{H}\right)$ is attributed to the protons of aromatic ring. The ${ }^{1} \mathrm{H}$ NMR spectra for NA [51] has proton signals at $\delta=7.46\left(\mathrm{~s}, 1 \mathrm{H}, \mathrm{C}_{2}-\mathrm{H}\right), 8.48$ $\left(\mathrm{d}, 1 \mathrm{H}, \mathrm{C}_{4}-\mathrm{H}\right), 7.55\left(\mathrm{t}, 1 \mathrm{H}, \mathrm{C}_{5}-\mathrm{H}\right), 8.36\left(\mathrm{~d}, 1 \mathrm{H}, \mathrm{C}_{6}-\mathrm{H}\right)$ and $5.14 \mathrm{ppm}\left(\mathrm{s}, 2 \mathrm{H}, \mathrm{NH}_{2}\right)$. In the ${ }^{1} \mathrm{H}$ NMR spectra of the synthesized complex, the location of the $\mathrm{CH}_{2}$ moieties bound to $\mathrm{O}$ atoms in the $\mathrm{Pt}(\mathrm{II})$ complex is shifted in compared to that of the BBHMP, suggesting deshielding of the protons of the $\mathrm{CH}_{2}$ moieties because of its binding to $\mathrm{Pt}^{2+}$ ion via the $\mathrm{O}$ atoms of BBHMP. In addition, $\mathrm{OH}$ peaks disappeared and small shifts are observed in other values.

The thermal analysis results of the obtained complex are summarized in Table 3 . In the thermal behaviour of the complex, the 1 st step with a weight loss of $0.3 \%$ is in the range of $25-200^{\circ} \mathrm{C}$ due to the removal of possible water molecules. The $2 \mathrm{nd}$ step between $200-600^{\circ} \mathrm{C}$ is the decomposition of the organic compound $+\mathrm{Cl}(56.6 \%)$. The range $600-800^{\circ} \mathrm{C}$ indicates the formation of $2 \mathrm{~mol}$ PtO (47.2 $\mathrm{Q}$ ) and the compound remaining over $800^{\circ} \mathrm{C}$ was determined to be $2 \mathrm{~mol} \mathrm{Pt}(43.1 \%)$. Molecular weight ratio of the amount of PtO and Pt show very good agreement for the proposed structure according to the TGA data $[38,52]$. 
Table 3

Thermal analysis decompositions of the Pt(II) complex

\begin{tabular}{|lllll|}
\hline Compound & Steps & ${\text { Tb-Tc }\left({ }^{\circ} \mathrm{C}\right)}$ & Weight loss $(\mathbb{\nabla})$ & Assignments \\
\hline Pt (II) complex & 1st & $25-200$ & 0.3 & Possible water molecule \\
\hline 2nd & $200-600$ & 56.6 & Organic Compound $+\mathrm{Cl}$ \\
\hline 3rd & $600-800$ & 47.2 & 2 PtO \\
\hline 4th & $800-1000$ & 43.1 & $2 \mathrm{Pt}$ \\
\hline
\end{tabular}

\section{Solution Study Results}

The stability with time of Pt(II) complex in a physiological buffer was studied by UV-Visible spectrophotometer [53-55]. The complex was dissolved in DMSO (5 mM) and physiological buffer $(0.1$ $\mathrm{M}$ phosphate, $4 \mathrm{mM} \mathrm{NaCl}, \mathrm{pH}$ 7.4). The stability of $\mathrm{Pt}(\mathrm{II})$ complex was determined spectrophotometrically. The electronic spectra of complex were determined with the evolution of time over $18 \mathrm{~h}$ (Fig. 2). According to Fig. 2, the transitions between 250 and $450 \mathrm{~nm}$ are stable over $18 \mathrm{~h}$, confirming that the synthesized complex is stable when dissolved in a physiological buffer.

\section{Antimicrobial Activity Results}

As antimicrobial activity of NA were reported in literature [14-16,56,57], in the present study, the antimicrobial activities of the BBHMP and platinum(II) complex by using micro broth dilution method were investigated against bacterial and fungal strains that can ensure resistance to antibiotics through biochemical changes and minimal inhibition concentration values (MIC) values were found. The antimicrobial activities of the BBHMP and its platinum(II) complex were investigated against bacterial and fungal strains since these strains can confirm the resistance to antibiotics through biochemical changes. The antimicrobial activity results are presented Fig. 3 and Table 4. In the previous studies, Antibacterial and antifungal activities of various Pt(II) complexes are seen to exhibit a broad spectrum of antimicrobial activity. In the previous studies [58-60], antibacterial and antifungal activities of various $\mathrm{Pt}$ (II) complexes are seen to have significant antimicrobial activity. When compared with the antimicrobial activity values in these studies, the Pt(II) complex we synthesized has significant activity especially against Staphylococcus Aureus strain. According to the obtained results, while the free BBHMP shows moderate antimicrobial activity against Salmonella aureus and Escherichia coli at $6.25 \mu \mathrm{g} / \mathrm{mL}$ concentrations, the complex has moderate effect against Salmonella aureus and Candida albicans at 25 and $50 \mu \mathrm{g} / \mathrm{mL}$ concentrations. These results show that the complex is more active against fungi. As a result, the complex indicates increased antimicrobial activity compared with BBHMP. This important activity of the complex may be because of the polarity of the metal and the change in the structure of the 
complex. This can be explained by partially sharing the positive charge on $\mathrm{Pt}(\mathrm{II})$ with the donor groups, such as $\mathrm{N}$ and $\mathrm{O}$ on the BBHMP and NA.

Table 4

Antimicrobial activity values for the BBHMP and Pt(II) complex

\begin{tabular}{|lll|}
\hline Name of organisms & $\begin{array}{l}\text { Inhibition } \% \\
\text { BBHMP/Antibiotic (Complex/Antibiotic) }\end{array}$ & $\begin{array}{l}\text { MIC }(\mu \mathrm{g} / \mathrm{mL}) \\
\text { BBHMP/Antibiotic } \\
\text { (Complex/Antibiotic) }\end{array}$ \\
\hline E. coli & $36 / 28(69 / 11)$ & $6.25 / 6.25(6.25 / 6.25)$ \\
\hline S. typhimurium & $66 / 31(72 / 18)$ & $12.5 / 6.25(200 / 6.25)$ \\
\hline S. aureus & $32 / 21(32 / 16)$ & $6.25 / 6.25(25 / 6.25)$ \\
\hline L. monocytogenes & $71 / 13(68 / 8)$ & $6.25 / 6.25(6.25 / 6.25)$ \\
\hline B. cereus & $70 / 34(72 / 10)$ & $6.25 / 6.25(12.5 / 6.25)$ \\
\hline C. albicans & $69 / 49(31 / 26)$ & $50 / 6.25(50 / 6.25)$ \\
\hline * Ampicillin and amphotericin B as antibiotic for bacterial and fungal strains.
\end{tabular}

\section{Cytotoxicity Results}

Anticancer treatments show cytotoxicity against cancer cell proliferation $[61,62]$. The cancer cells are cultured. After applying the procedure, the MTT assay is applied to check the proliferation or viability of the cells. The Pt(II) complexes indicate stimulating cytotoxicity [38,63-66]. In a previous study, four Pt(II) complexes with 2-substituted benzimidazole ligands were synthesized and their cytotoxicity activities were investigated against the human breast cancer (MCF7) cell line by Gümüş et al. [63]. Based on the reported test results, synthesized platinum complexes were determined to be less active than cisplatin, exhibited moderate cytotoxicity on the MCF 7 cell line. Due to the appreciable stability with time of the complex in DMSO under physiological-like conditions, the complex could be evaluated as potential cytotoxic agent. Previously, many studies were reported the cytotoxicity properties of NA [67-70]. Hence, the cytotoxicity of the BBHMP and its platinum(II) complex was examined for human prostate (DU145) and breast (MCF7) cancer cell lines with an MTT assay. For comparison purposes, cisplatin activity was evaluated under the same experimental conditions. The results are presented in Fig. 4. The cell viability (\%) of BBHMP and Pt(II) complex-treated DU145 and MCF7 cancer cells was effective at 100, 200, 400 and $800 \mu \mathrm{M}$ concentrations for 24 hours compared to their respective control groups. The $\mathrm{IC}_{50}$ values within the micromolar range (50\% inhibition) were found from the dose response curves (Table 5). As a result of probit analysis, the $\mathrm{IC}_{50}$ data were of $\mathrm{BBHMP}$ and platinum complex were determined as 94.72 
and $81.96 \mu \mathrm{M}$ for DU145 and found as 74.42 and $67.27 \mu \mathrm{M}$ for MCF7, respectively. Although the $\mathrm{IC}_{50}$ values of the BBHMP and complex were higher than cisplatin in DU145 and MCF7 cancer cells, they showed moderate cytotoxicity against the same cancer cells. As a result, the cytotoxicity of the complex is more effective than free BBHMP and NA. In comparison with previously reported literature $\mathrm{IC}_{50}$ data $[63,71-73]$, the synthesized complex was evaluated to be less effective toward the DU145 and MCF7.

Table 5

$\mathrm{IC}_{50}(\mu \mathrm{M})$ values of cytotoxicty activity of the BBHMP and Pt(II) complex

\begin{tabular}{|lll|}
\hline & $\mathrm{IC}_{\mathbf{5 0}}(\boldsymbol{\mu M})$ & \\
\hline Compound & Du145 & MCF7 \\
\hline BBHMP & $94.72 \pm 2.73$ & $74.42 \pm 2.19$ \\
\hline Complex & $81.96 \pm 2.89$ & $67.27 \pm 1.36$ \\
\hline cisplatin & $20.92 \pm 0.49$ & $18.87 \pm 0.55$ \\
\hline
\end{tabular}

\section{Gene Expression Results}

Some anticancer agents, in particular phenolic compound-inducible molecules, have been linked to activation of apoptosis signaling pathways in cancer cells. Recently, it was reported that Pt(II) complexes is a anticancer drug candidate. In one of the studies for this purpose [74], the effects of a series of tetrazolato-bridged dinuclear $\mathrm{Pt}(\mathrm{II})$ complexes were synhesized and investigated theirs gene expressions. The results indicated that these complexes were highly inhibitory effects of these drugs on gene expression. Hence, in this study, the apoptotic effect of the BBHMP and Pt(II) complex was investigated on DU145 and MCF7 cancer cells using gene expression profiles. Gene expression results are given in Fig. 5. According to Fig. 5, selected genes related to the apoptosis inhibitor, apoptosis activator and cell cycle control groups were determined using the qRT-PCR method. In all cancer cells, while tumor suppressor P53 increases, BCL-2 gene expression is suppressed and pro-apoptotic BAX gene expression increases. Increasing BAX expression triggers the release of Cyt-C from mitochondrial membranes. This gene is linked to APAF 1 and activates caspase 3. As a result of the increase in the expression of caspase 3 , death is observed in cancer cells.

\section{Antioxidant Activity Results}

The DPPH radical scavenging method [75-78], which is widely used in antioxidant activity studies and determined rapidly with UV-Visible spectrophotometer, was studied at different concentrations for the antioxidant activities of the BBHMP, NA and Pt (II) complex. The $\mathrm{IC}_{50}$ value is the concentration of the 
sample causing a $50 \%$ reduction in DPPH concentration and and is obtained from linear regression of the concentration plots of the tested compounds against the mean percentage of antioxidant activity [79]. The lower the IC50 value, the higher the antioxidant activity of the samples tested. The antioxidant results and $\mathrm{IC}_{50}$ values of antioxidant activity for BBHMP, NA and complex are given in Fig. 6 and Table 6 . According to the antioxidant results, antioxidant activity was effectively increased as a result of the electron withdrawing effect of the platinum(II) ion. The complex also indicated important free radical scavenging when studied against DPPH. Finally, it was evaluated that antioxidant activity of BBHMP and NA were increased on complexation with $\mathrm{Pt}^{2+}$ ion. In comparison with previously reported antioxidant data $[58,80,81]$, the complex indicated significant antioxidant activity.

Table 6

$\mathrm{IC}_{50}(\mu \mathrm{M})$ values of

antioxidant activity of the

BBHMP, NA and Pt(II) complex

\begin{tabular}{|ll|}
\hline Compound & $\mathrm{IC}_{50}(\mu \mathrm{M})$ \\
\hline BBHMP & $0.40 \pm 1.20$ \\
NA & $0.48 \pm 1.23$ \\
Complex & $0.34 \pm 1.17$ \\
BHT & $0.28 \pm 1.32$ \\
\hline
\end{tabular}

\section{Conclusions}

In this work, a platinum(II) complex with BBHMP (4-Bromo-2,6-bis-hydroxymethyl-phenol) and NA (nicotinamide) was synthesized. The obtained complex was characterized by using spectral and thermal analysis. According to results, BBHMP and NA molecules are coordinated $\mathrm{Pt}^{2+}$ ions through oxygen and nitrogen atoms with the square-planar structure. The reaction of BBHMP and NA with $\mathrm{Pt}(\mathrm{II})$ is a complexation reaction. One molecule of BBHMP and two molecules of NA that react with two molecules of the $\mathrm{Pt}$ (II) ion. The two Pt atoms are connected to each other via phenolic oxygen and $\mathrm{Cl}$ bridge. Load balance has been achieved with 3 oxygen atoms of $\mathrm{BBHMP}$ and one $\mathrm{Cl}$ atoms. Elemental analysis and ESI-MS results support the proposed form and the closed formula. From antimicrobial activity results, it is determined that BBHMP and complex are active against some of the bacterial and fungal strains. Additionally, Cytotoxicity results suggest that the Pt(II) complex and free ligands have reasonable toxic activity. The BBHMP and Pt(II) complex indicate strong cell-growth inhibition against human prostate (DU145) and breast (MCF7) cancer cell lines with used MTT assay. There is complex-induced apoptosis in these cancer cells with $\mathrm{IC}_{50}: 94.72$ and $74.42 \mu \mathrm{M}$ for BBHMP and 81.96 and $67.27 \mu \mathrm{M}$ for $\mathrm{Pt}(\mathrm{II})$ complex, respectively. Several cellular parameters were found using qRT-PCR assay. The experiments 
revealed that the BBHMP and complex may cause cell death in DU145 and MCF7 cancer cells by inducing mitochondrial membrane permeability change which leads to cytochrome $c$ release resulting in apoptotic cell death. In addition, BBHMP, NA and Pt(II) complex have important antioxidant activity.

\section{Declarations}

Funding This study was financially supported by Trakya University. Research Fund (TUBAP, project \# 2016/72). The antimicrobial, cytotoxicity and gen expression analysis of the BBHMP and synthesized Pt(II) complex were performed by Trakya University Research Unit (TUTAGEM).

Availability of data and material All the data analyzed has been included in the manuscript and supplementary material.

Code availability Not applicable

Authors'contributionsö. A. - Investigation, writing, review and editing, Conceptualization, methodology, formal analysis, resources, visualization. Z. Y. - Investigation, writing, review and editing, Conceptualization, methodology, formal analysis, resources, visualization. M. B. - Writing, review and editing, Conceptualization, methodology, formal analysis, resources, visualization.

Ethics approval This article does not contain any studies with human participants or animals performed by any of the authors.

\section{Compliance with ethical standarts}

Consent to participate All the authors agreed to participate in the scientific work.

Consent for publication All the authors agreed to submit the manuscript.

Competing of Interests The authors declare that there is no conflict of interest.

\section{References}

[1] Yonemura, M., Arimura, K., Inoue, K., Usuki, N., Ohba, M., Ohkawa, H. (2002). Coordination-position isomeric $\mathrm{M}^{\prime \prime} \mathrm{Cu}^{\prime \prime}$ and $\mathrm{Cu}^{\prime \prime} \mathrm{M}^{\prime \prime}(\mathrm{M}=\mathrm{Co}, \mathrm{Ni}, \mathrm{Zn}$ ) complexes derived from macrocyclic compartmental ligands. Inorg. Chem., 41 (3), 582-589. https://doi.org/10.1021/ic010499d

[2] Rajendiran, T.M., Kannappan, R., Mahalakshmy, R., Rajeswari, J., Venkatesan, R., Rao, P. (2003). New unsymmetrical I-phenoxo bridged binuclear copper(II) complexes. Trans. Metal Chem., 28 (4), 447-454. https://doi.org/10.1023/A:1023662820857

[3] Ambrosi, G., Formica, M., Fusi, V., Giorgi, L., Micheloni, M. (2008). Polynuclear metal complexes of ligands containing phenolic units. Coord. Chem. Rev., 252 (10-11), 1121-1152.

https://doi.org/10.1016/j.ccr.2007.09.027 
[4] Zhou, Y., Zhang, J.F., Yoon, J. (2014). Fluorescence and colorimetric chemosensors for fluoride-ion detection. Chem. Rev., 114 (10), 5511-5571. https://doi.org/10.1021/cr400352m

[5] Tavallali, H., Deilamy-Rad, G., Tabandeh, A. (2011). A selevtive detection of fluoride ions in DMSO by fluorescent and colorimetry competition assays based on 4-bromo-2,6- bis(hydroxymethyl) phenol. Chinese Chem. Let., 22 (2), 193-196. https://doi.org/10.1016/j.cclet.2010.07.032

[6] Crisp, G.T., Turner, P.D., Tiekink, E.R.T. (200). Crystal structure of 4-bromo-2,6bis(hydroxymethyl)phenol, $\mathrm{CsH}_{9} \mathrm{BrO}_{3}$. Z. Kristallogr.,215, 443-444.

[7] Nahi, R.J., Hello, K.M. (2008). Synthesis and biological study of new ether derivatives of 2,6dimethylol-4- bromo- phenol. AL-Qadisiya J. Vet. Med. Sci., 7 (1), 1-5.

[8] Chokkanathan, U., Geetha, K. (2016). Synthesis, characterization and biological applications of a multidentate ligand and its copper(II) complexes. Int. J. App. Adv. Sci. Res. (IJAASR), 1 (2), 146-151.

[9] Altun, Ö., Yoruç, Z. (2018). Pd(II) complex with 4-bromo-bis-hydroxymethyl phenol and Nicotinamide: Synthesis and Spectral Analysis. World Academy Sci. Eng. Techn. Int. J. Chem. Mat. Eng.,12 (9), 471-474. http://doi.org/10.5281/zenodo.1474567

[10] Altun, Ö., Yoruç, Z. (2019). Synthesis, spectral analysis, and thermodynamic parameters of gold(III) complex in the presence of 4-bromo-2,6-bis(hydroxymethyl)phenol and $m$-nitroaniline. Monatshefte Fur Chemie, 150, 1785-1791. https://doi.org/10.1007/s00706-019-02498-0

[11] Lim, L.Y., Go, M.L. (2000). Caffeine and nicotinamide enhances the aqueous solubility of the antimalarial agent halofantrine. Eur. J. Pharm. Sci., 10 (1), 17-28. https://doi.org/10.1016/S09280987(99)00084-6

[12] Turan-Zitouni, G., Sıvacı, M., Kılıç, F.S., Erol, K. (2001). Synthesis of some triazolyl-antipyrine derivatives and investigation of analgesic activity. Eur. J. Med. Chem., 36 (7-8), 685-689. https://doi.org/10.1016/S0223-5234(00)00152-5

[13] Evstigneev, M.P., Evstigneev, V.P., Hernandez, Santiago A.A., Davies, D.B. (2006). Effect of a mixture of caffeine and nicotinamide on the solubility of vitamin (B2) in aqueous solution. Eur. J. Pharm. Sci., 28 (12), 59-66. http://dx.doi.org/10.1016/j.ejps.2005.12.010

[14] Lawal, A., Obaleye, J.A., Adediji, J.F., Amolegbe, S.A., Bamigboye, M.O., Yunus-Issa, M.T.L. (2008). Synthesis, Characterization and Antimicrobial Activities of Some Nicotinamide-metal complexes. J. Appl. Sci. Environ. Manage.,18 (2), 205-208. http://dx.doi.org/10.4314/jasem.v18i2.8

[15] Dilip, C.S., Thangaraj, V., Rai, A.P. (2016). Synthesis, spectroscopic characterisation, biological and DNA cleavage properties of complexes of nicotinamide. Arab. J. Chem.,9 (1), S731-S742. https://doi.org/10.1016/j.arabjc.2011.07.016 
[16] Tella, A.C., Owalude, S.O., Sunday, G.M. ,Olatunji, J., Adetitun, D.O., Kolawole, M.O. (2017). Synthesis, thermal properties, and biological study of metal(II) nicotinamide complexes containing fumarate dianion

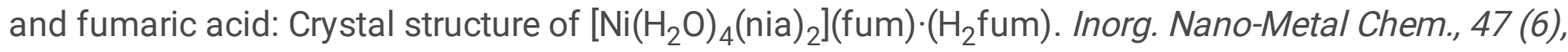
859-864. https://doi.org/10.1080/15533174.2016.1212234

[17] Izatt, R.M., Cristensen, J.J., Rytting, J.H. (1971). Sites and thermodynamic quantities associated with proton and metal ion interaction with ribonucleic acid, deoxyribonucleic acid, and their constituent bases, nucleosides, and and nucleotides. Chem. Rev.,71 (5), 439-481. https://doi.org/10.1021/cr60273a002

[18] Paşaoğlu, H., Güven, S., Heren, H. (2006). Synthesis, spectroscopic and structural investigation of $\mathrm{ZnI}_{2}$ (nicotinamide) ${ }_{2}, \mathrm{ZnI}_{2}$ (isonicotinamide) ${ }_{2}$ and $\left[\mathrm{Zn}\left(\mathrm{H}_{2} \mathrm{O}\right)_{2} \text { (picolinamide) }{ }_{2}\right]_{2}$. J. Mol. Struc. 794 (1-3), 270-276. https://doi:10.1016/j.molstruc.2006.02.045

[19] Cakır, S. Biçer, E. Aoki, K. Coşkun, E. (2006). Voltammetric and Spectroscopic Studies of Vanadium(V)-Nicotinamide Interactions at Physiological pH. Cryst. Res. Tech.,41 (3), 314-320.

[20] Hokelek, T., Yavuz, V., Dal, H., Necefoğlu, H. (2018). Crystal structure and Hirshfeld surface analysis of aqua-bis-(nicotinamide-kN)bis-(4-sulfamoylbenzoato-k01)copper(II). Acta Crystallogr. E Crystallogr. Commun.,74 (Pt 1), 45-50. https://doi:10.1107/s2056989017017765

[21] Clinical and Laboratory Standards Institute (2002). Reference method for broth dilution antifungal susceptibility testing of yeasts: approved standard M27-A2, Wayne (PA): CLSI.

[23] Clinical and Laboratory Standards Institute (2012). Performance standards for antimicrobial susceptibility testing, 15th Informational Supplement. CLSI Document M100-S22, PA.

[22] Wiegand, I., Hilpert, K., Hancock, R.E.W. (2008). Agar and broth dilution methods to determine the minimal inhibitory concentration (MIC) of antimicrobial substances. Nature Protocols, 3 (2), 163-175. https://doi.org/10.1038/nprot.2007.521

[24] Kaya, E., Ozbilge, H. (2012). Determination of the effect of fluconazole against Candida albicans and Candida glabrata by using microbroth kinetic assay.Turk. J. Med. Sci.,42 (2), 325-328. https://doi.org/10.3906/sag-1010-1211

[25] Altun, Ö., Koçer, M.Ö. (2020). Pt(II) complex of Schiff base derived from L-phenylalanine and furfuraldehyde in the presence of 8-hydroxyquinoline: Structural analysis, composition of complex and biological activity. Compres Rendus Chimie,23 (2), 127-142. https://doi.org/10.5802/crchim.9

[26] Kim, R., Emi, M., Tanabe, K. (2006). Role of mitochondria as the gardens of cell death. CancerChemoth Pharm., 57 (5), 545-553. https://doi.org/10.1007/s00280-005-0111-7

[27] Amani, V., Abedi, A., Ghabeshi, S., Khavasi, H.R., Hosseini, S.M., Safari, N. (2014). Synthesis and characterization of a series of gold(III) complexes with the 4,40-dimethyl-2,20-bipyridine ligand: 
Counterion influence on the cytotoxicity of gold(III) complexes. Polyhedron,79, 104-115. https://doi.org/10.1016/j.poly.2014.04.064

[28] Doğanlar, O., Doganlar, Z.B. (2015). Evaluation of the selective anticancer potential and the genetic mechanisms of the induction of apoptosis by walnut milk in human breat and prostate cancer cells. Biomed. Res. Int.,27 (1), 1-11.

[29] Sathiyaraj, S., Butcher, R.J., Jayabalakrishnan, C. (2012). Synthesis, characterization, DNA interaction and in vitro cytotoxicity activities of ruthenium(II) Schiff base complexes.J. Mol. Struct.,1030, 95-103. https://doi.org/10.1016/j.molstruc.2012.07.021

[30] Hongmei, Z. (2002). Apoptosis and Medicine: Extrinsic and intrinsic apoptosis signal pathway review in biochemistry, Genetics and Molecular Biology, T.M. Ntuli, ed.

[31] Fulda, S., Debatin, K.M. )2006). Debatin, Extrinsic versus intrinsic apoptosis pathways in anticancer chemotherapy. Oncogene, 25 (34), 4798-4811. https://doi.org/10.1038/sj.onc.1209608

[32] Güçlü, H., Doganlar, Z.B., Gürlü, V.P., Özal, A., Dogan, A., Turhan, M.A., Doganlar, O. (2018). Effects of cisplatin-5-fluorouracil combination therapy on oxidative stress, DNA damage, mitochondrial apoptosis, and death receptor signalling in retinal pigment epithelium cells. Cutaneous and Ocular Toxicology,37 (3), 291-304. https://doi.org/10.1080/15569527.2018.1456548

[33] Zaim, Ö., Doğanlar, O., Zreigh, M.M., Doğanlar, Z.B., Özcan, H. (2018). Synthesis, Cancer-Selective Antiproliferative and Apoptotic Effects of Some ( \pm )-Naringenin Cycloaminoethyl Derivatives. Chem. Biodivers.,15 (7) e1800016, 1-15. https://doi.org/10.1002/cbdv.201800016

[34] Blois, M.S. (1958). Antioxidant Determinations by the Use of a Stable Free Radical. Nature, 181 (4617), 1199-1200. http://dx.doi.org/10.1038/1811199a0

[35] Choudhary, A., Sharma, R., Nagar, M., Mohsin, M., Meena, H.S. (2011). Synthesis, characterization and antioxidant activity of some transition metal complexes with terpenoid derivatives. J. Chil. Chem. Soc.,56 (4), 911-917. http://dx.doi.org/10.4067/S0717-97072011000400019

[36] El-Gammal, O.A., Mostafa, M.M. (2014). Synthesis, characterization, molecular modeling and antioxidant activity of Girard's T thiosemicarbazide and its complexes with some transition metal ions. Spectrochim. Acta Part A,127, 530-542. http://dx.doi.org/10.1016/j.saa.2014.02.001

[37] Hristea, E.N., Caproiu, M.T., Pencu, G., Hillebrand, M., Constantinescu, T., Balaban, A.T. (2006). Reaction of 2,2-Diphenyl-1-picrylhydrazyl with $\mathrm{HO} \cdot, \mathrm{O} 2 \cdot-, \mathrm{HO}-$, and $\mathrm{HOO}$ - Radicals and Anions. Int. J. Mol. Sci.,7, 130-143. https://doi.org/10.3390/i7050130

[38] Al-Saif, F.A. (2014). Spectroscopic Elucidation, Conductivity and Activation Thermodynamic Parameters Studies on Pt(IV), Au(III) and Pd(II) 1,5-Dimethyl-2-phenyl-4-[(thiophen-2-ylmethylene)amino]-1,2-dihydro-pyrazol-3-one Schiff Base Complexes. Int. J. Electrochem. Sci., 9, 398-417. 
[39] Kettle, S.F.A. (1975). Coordination Compounds, Thomas Nelson and Sons, London.

[40] Geary, W.J. (1971). The use of conductivity measurements in organic solvents for the characterisations of coordination compounds. Coord. Chem. Rev.,1, 81-122.

http://dx.doi.org/10.1016/S0010-8545(00)80009-0

[41] Dyer, J.R. (1965). Application of Absorption Spectroscopy of Organic Compounds, Prentice-Hall, New Jersey.

[42] Siiman, O., Fresco, J. (1970). Electronic Spectra of the Dithioacetylacetone Complexes of Nickel(II), Palladium(II), and Platinum(II). J. Am. Chem. Soc.,92 (9), 2652-2656.

https://doi.org/10.1021/ja00712a011

[43] Lever, A.B.P. (1984). Inorganic Electronic Spectroscopy, 2nd ed., Elsevier, New York.

[44] Agarwal, R.K., Prasad, S. (2005). Synthesis and Spectral Investigations of Some Platinum Metals Ions Coordination Compounds of 4[N-(Furan-2'-carboxalidene) Amino] Antipyrine Thiosemicarbazone and 4[N-(3',4',5'-Trimethoxybenzalidene) Amino] Antipyrine Thiosemicarbazone. Turk. J. Chem.,29 (3), 289298. https://dergipark.org.tr/en/pub/tbtkchem/issue/11928/142636

[45] Socrates, G. (1980). Infrared Characterization Group Frequencies, John Wiley and Sons, New York.

[46] NIST Chemistry Web Book, SRD 69. https://dx.doi.org/10.18434/T4D303

[47] Simpson, N., Shaw, D.J., Frederix, P.W.J.M., Gillies, A.H., Adamczyk, K., Greetham, G.M., Towrie, M., Parker, A.W., Hoskisson, P.A., Hunt, N.T. (2013). Infrared Spectroscopy of Nicotinamide Adenine Dinucleotides in One and Two Dimensions. J. Phys. Chem.,B 117 (51), 16468-16478. https://doi.org/10.1021/jp411091f

[48] Nakamato, K., Morimoto, V., Martell, A.E. (1961). Infrared Spectra of Aqueous Solutions. I. Metal Chelate Compounds of Amino Acids. J. Am. Chem. Soc.,83 (22), 4528-4532. https://doi.org/10.1021/ja01483a010

[49] Nakamato, K. (1997). Infrared and Raman Spectra of Inorganic and Coordination Compounds, 5th ed., John Wiley and Sons, New York.

[50] Lambert, J.B., Shurwell, H.F., Verbit, L., Cooks, R.G., Stout, G.H. (1976). Organic Structural Analysis, Mac Millan, New York.

[51] Olsen, R.A., Liu, L., Ghaderi, N., Johns, A., Hatcher, M.E., Mueller, L.J. (2003). The Amide Rotational Barriers in Picolinamide and Nicotinamide: NMR and ab Initio Studies. J. Am. Chem. Soc., 125 (33), 10125-10132. https://doi.org/10.1021/ja028751j 
[52] Giovagnini, L., Ronconi, L., Aldinucci, D., Lorenzon, D., Sitran, S., Fregona, D. (2005). Synthesis, characterization, and comparative in vitro cytotoxicity studies of platinum(II), palladium(II), and gold(III) methylsarcosinedithiocarbamate complexes. J. Med. Chem.,48 (5), 1588-1595. https://doi.org/10.1021/jm049191x

[53] Carotti, S., Guerri, A., Mazzei, T., Messori, L., Mini, E., Orioli, P. (1998). Gold(III) compounds as potential antitumor agents: Cytotoxicity and DNA binding properties of some selected polyamine-gold(III) complexes. Inorg. Chim. Acta,281, 90-94. https://doi.org/10.1016/S0020-1693(98)00148-0

[54] Abbate, F., Orioli, P., Bruni, B., Marcon, G., Messori, L. (2000). Crystal structure and solution chemistry of the cytotoxic complex 1,2-dichloro(o-phenanthroline)gold(III) chloride. Inorg. Chim. Acta,311, 1-5. https://doi.org/10.1016/S0020-1693(00)00299-1

[55] Casini, A., Diawara, M.C., Scopelliti, R., Zakeeruddin, S.M., Gratzel, M., Dyson, P.J. (2010). Synthesis, characterisation and biological properties of gold(III) compounds with modified bipyridine and bipyridylamine ligands. Dalton Trans.,39, 2239-2245. https://doi.org/10.1039/B921019A

[56] Murray, M.F. (2003). Nicotinamide: an oral antimicrobial agent with activity against both Mycobacterium tuberculosis and human immunodeficiency virüs. Clin. Infect. Dis., 36 (4), 453-460. https://doi.org/10.1086/367544

[57] Zidan, A.S., Ahmed, O.A., Aljaeid, B.M. (2016). Nicotinamide polymeric nanoemulsified systems: a quality-by-design case study for a sustained antimicrobial activity. Int.J. Nanomedicine, 11, 1501-1516. https://doi.org/10.2147/IJN.S102945

[58] Filipovic, N.R., Markovic, I., Mitic, D., Polovic, N., Milcic, M., Dulovic, M., Jovanovic, M., Savic, M., Niksic, M., Andelkovic, K., Todorovic, T. J. (2014). A comparative study of in vitro cytotoxic, antioxidant, and antimicrobial activity of $\mathrm{Pt}(\mathrm{II}), \mathrm{Zn}(\mathrm{II}), \mathrm{Cu}(\mathrm{II})$, and $\mathrm{Co}(\mathrm{III})$ complexes with N-heteroaromatic Schiff base (E)-2-[N'-(1-pyridin-2-yl-ethylidene)hydrazino]acetate. Biochem. Mol. Toxicol.,28 (3), 99-110. https://doi.org/10.1002/jbt.21541

[59] Al-Hamdani, A.A.S., Balkhı, A.M., Falah, A., Shaker, S.A. (2015). New azo-Schiff base derived with $\mathrm{Ni}(\mathrm{II}), \mathrm{Co}(\mathrm{II}), \mathrm{Cu}(\mathrm{II}), \mathrm{Pd}(\mathrm{II})$ and $\mathrm{Pt}(\mathrm{II})$ complexes: preparation, spectroscopic investigation, structural studies and biological activity. J. Chil. Chem. Soc., 60 (1), 2774-2785. http://dx.doi.org/10.4067/S071797072015000100003

[60] Pahontu, E., Paraschivescu, C., llies, D.C., Poirier, D., Oprean, C., Paunescu, V., Gulea, A., Rosu, T., Bratu, O. (2016). Synthesis and Characterization of Novel $\mathrm{Cu}(\mathrm{II}), \mathrm{Pd}(\mathrm{II})$ and Pt(II) Complexes with 8-Ethyl-2hydroxytricyclo(7.3.1.02,7)tridecan-13-onethiosemicarbazone: Antimicrobial and in Vitro Antiproliferative Activity. Molecules,21 (5), 1-18. https://doi.org/10.3390/molecules21050674

[61] Gomez, G.D., Chavez, J.D., Blanco, A.C., Fierro, A.G., Salazar, J.E.J., Matsumura, P.D., Quiroz, L.E.G., Gonzalez, A.D. (2015). Nicotinamide sensitizes human breast cancer cells to the cytotoxic effects of 
radiation and cisplatin. Oncology Reports,33 (2), 721-728. https://doi.org/10.3892/or.2014.3661

[62] Blagosklonny, M.V., Pardee, A.B.(2001). Exploiting cancer cell cycling for selective protection of normal cells. Cancer Res., 61 (11), 4301-4305.

[63] Gümüş, F., Algül, O., Eren, G.; Eroğlu, H., Diril, N., Gür, S., Özkul, A. (2003). Synthesis, cytotoxic activity on MCF-7 cell line and mutagenic activity of platinum(II) complexes with 2-substituted benzimidazole ligands. Eur. J. Med. Chem.,38 (5), 473-480. https://doi.org/10.1016/s0223-5234(03)00058-8

[64] Li, L.J., Wang, C., Tian, C., Yangi, X.Y., Hua, X.X., Du, J.L. (2013). Water-soluble platinum(II) complexes of reduced amino acid Schiff bases: synthesis, characterization, and antitumor activity. Res. Chem. Intermediat.,39(2), 733-746. https://doi.org/10.1007/s11164-012-0593-

[65] Volarevic, V., Vujic, J.M., Milovanovic, M., Kanjevac, T., Volerevic, A. Trifunovic, S.R., Arsenijevic, N. (2013). Cytotoxic effects of palladium(II) and platinum(II) complexes with O, O'-dialkyl esters of (S, S)ethylenediamine-N,N'-di-2-(4-methyl) pentanoic acid on human colon cancer cell lines. J. BUON.,18 (1), 131-137.

[66] Mukherjee, S., Mitra, I., Reddy, V.P.B., Fouzder, C., Mukherjee, S., Ghosh, S., Chatterji, U. (2017). Effect of Pt(II) complexes on cancer and normal cells compared to clinically used anticancer drugs: Cell cycle analysis, apoptosis and DNA/BSA binding study. Journal of Molecular Liquids,247, 126-140. https://doi.org/10.1016/j.molliq.2017.09.104

[67] Pranczk, J., Jacewicz, D., Wyrzykowski, D., Chmurzynski, L. (2014). Platinum(II) and Palladium(II) Complex Compounds as Anti-cancer Drugs. Methods of Cytotoxicity Determination. Curr. Pharm. Anal.,10 (1), 2-9. https://doi.org/10.2174/157341291001140102103324

[68] Ito, K., Sugita, Y., Saito, T., Komatsu, S., Sato, N., Isomur, M., Yoshida, W., Kubo, K., Maeda, H. (2016). Effects of nicotinamide on cytotoxicity-induced morphological changes in osteoblastic cells in vitro. $J$. Hard Tissue Biology,25 (4), 357-364. https://doi.org/10.2485/jhtb.25.357

[69] Peng, M., Shi, L., Ke, S. (2017). Nicotinamide-based diamides derivatives as potential cytotoxic agents: synthesis and biological evaluation. Chem. Cent. J.,11 (109), 1-9.

https://doi.org/10.1186/s13065-017-0338-5

[70] Alee, M., Khaghani, S., Behroozfar, K., Hesari, Z., Ghorbanhosseini, S.S., Nourbakhsh, M. (2017). Inhibition of nicotinamide phosphoribosyltransferase induces apoptosis in ostrogen receptor-positive MCF7 breast cancer cells. J. Breast Cancer,20 (1), 20-26. http://dx.doi.org/10.4048/jbc.2017.20.1.20

[71] Plutin, A.M., Alvarez, A., Mocelo, R., Ramos, R., Sanchez, O.C., Castellano, E.E., Da Silva, M.M., Villarreal, W. ,Colina-Vegas, L,. Pavan, F.R., Batista, A.A. (2018). Structure/Activity of Pt"/N,N-Disubstituted$\mathrm{N}$-acylthiourea Complexes: Anti-Tumor and Anti-Mycobacterium tuberculosis Activities. J. Braz. Chem. Soc.,29 (6), 1256-1267. https://dx.doi.org/10.21577/0103-5053.20170222 
[72] Momeni, B.Z., Fathi, N., Janczak, J., Shahsavari, Z. (2019). Dihaloplatinum(II) complexes having diimine ligands: crystal structure, thermal properties, cytotoxicity effects against breast cancer cells and application as a precursor towards nanoparticles. J. Coord. Chem.,72 (4), 619-632. https://doi.org/10.1080/00958972.2019.1568420

[73] Maji, M., Karmakar, S., Ruturaj; Gupta, A., Mukherjee, A. (2020). Oxamusplatin: a cytotoxic Pt(ii) complex of a nitrogen mustard with resistance to thiol based sequestration displays enhanced selectivity towards cancer. Dalton Trans., 49 (8), 2547-2558. https://doi.org/10.1039/C9DT04269E

[74] Shimizu, Y., Yoshikawa, Y., Kenmotsu, T., Komeda, S., Yoshikawa, K. (2017). Conformational transition of DNA by dinuclear Pt(II) complexes causescooperative inhibition of gene expression. Chemical Physics Letters,678, 123-129. https://doi.org/10.1016/j.cplett.2017.04.039

[75] Isbilir, S., Orak, H.H., Yağar, H., Ekinci, N. (2012). Determination of antioxidant activities of strawberry tree (Arbutus unedo L.) flowers and fruits at different ripening stages. Acta Sci.Pol. Hortorum Cultus, 11 (3), 223-237.

[76] Sanna, V., Pala, N., Dessi, G., Manconi, P., Mariani, A., Dedola, S., Rassu, M.; Crosio, C., laccarino, C., Sechi, M. (2014). Single-step green synthesis and characterization of gold-conjugated polyphenol nanoparticles with antioxidant and biological activities. Int. J. Nanomed.,9, 4935-4951. https://doi.org/10.2147/IJN.S70648

[77] Ejidike, I.P., Ajibade, PA. (2015). Synthesis, Characterization, Anticancer, and Antioxidant Studies of $\mathrm{Ru}$ (III) Complexes of Monobasic Tridentate Schiff Bases. Bioinorg. Chem. Appl., 1- 9. http://dx.doi.org/10.1155/2016/9672451

[78] Simic, V., Kolarevic, S., Brceski, I., Jeremic, D., Vukovic-Gacic, B. (2016). Cytotoxicity and antiviral activity of palladium(II) and platinum(II) complexes with 2-(diphenylphosphino)benzaldehyde 1adamantoylhydrazone. Turk. J. Biol.,40, 661-669. https://doi.org/10.3906/biy-1503-23

[79] Saritha, V., Anilakumar, K.R., Khanum, F. (2010). Antioxidant and antibacterial activity of Aloe vera gel extracts. Int. J. Pharm. Biol. Arch., 1 (4), 376-384.

[80] Icsel, C., Yılmaz, V.T., Kaya, Y., Samli, H., Harrison, W.T.A., Buyukgungor, O. (2015). New palladium(II) and platinum(II) 5,5-diethylbarbiturate complexes with 2-phenylpyridine, 2,2'-bipyridine and 2,2'dipyridylamine: synthesis, structures, DNA binding, molecular docking, cellular uptake, antioxidant activity and cytotoxicity. Dalton Trans.,44, 6880-6895. https://doi.org/10.1039/C5DT00728C

[81] Srivastava, P., Singh, K., Verma, M., Sivakumar, S., Patra, A.K. (2018). Photoactive platinum(II) complexes of nonsteroidal anti-inflammatory drug naproxen: Interaction with biological targets, antioxidant activity and cytotoxicity. Eur. J. Med. Chem.. 144, 243-254.

https://doi.org/10.1016/j.ejmech.2017.12.025 
Figures

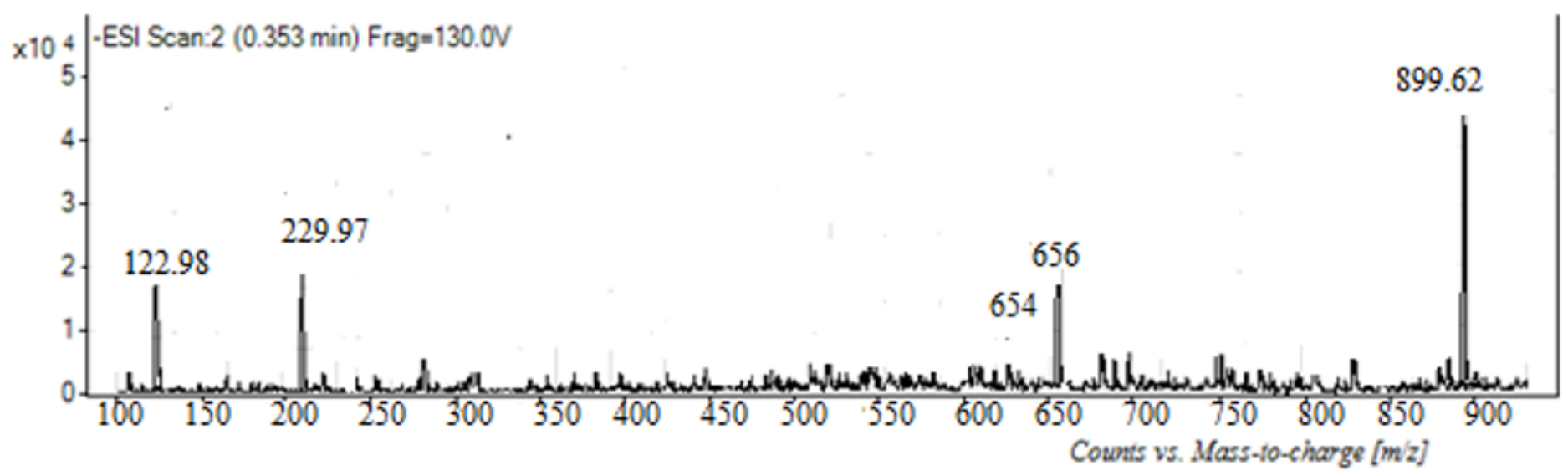

Figure 1

ESI-MS spectra of the Pt(II) complex in $\mathrm{CH} 3 \mathrm{OH}$

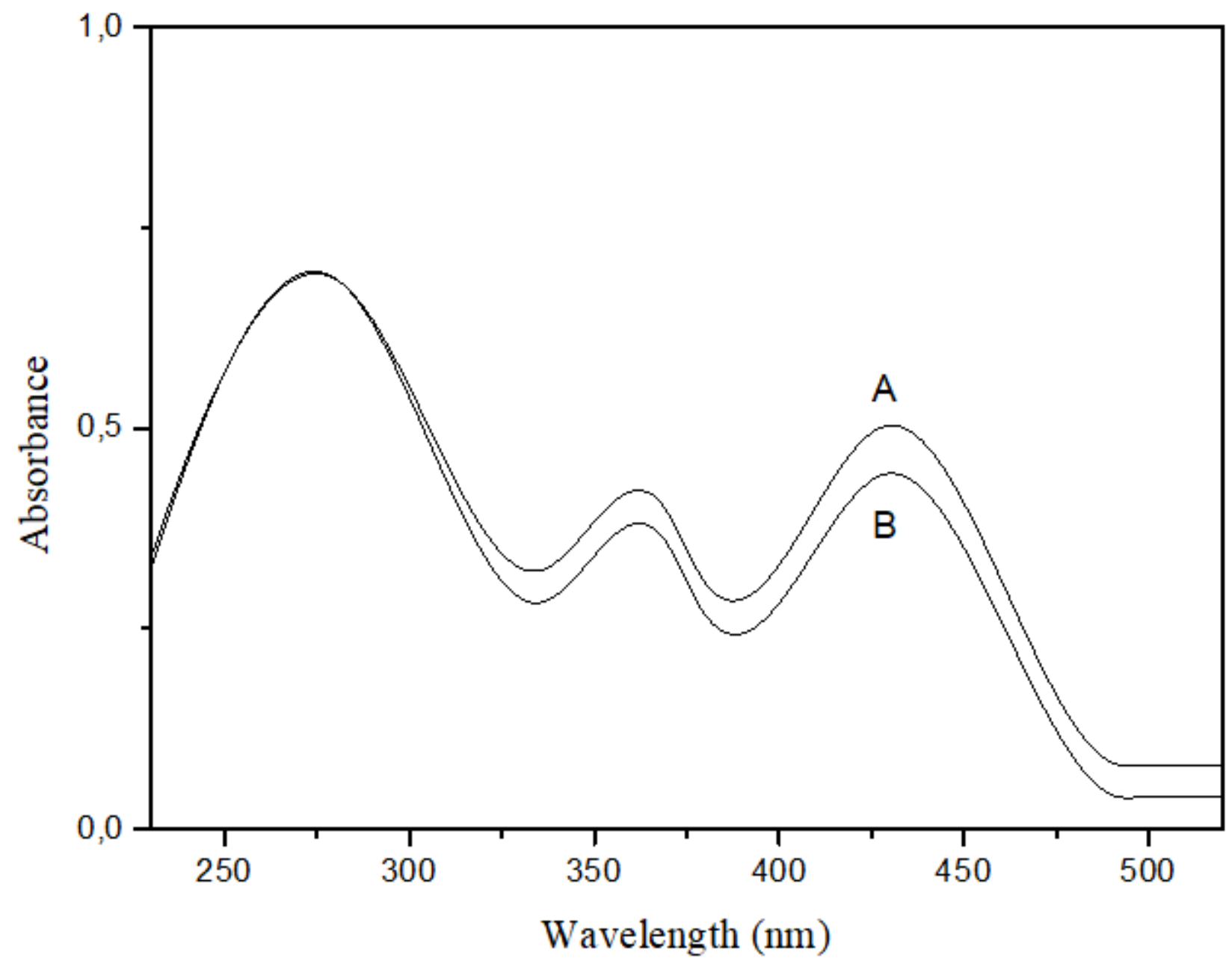

Figure 2 
UV-Vis. spectrum of the Pt(II) complex in DMSO under physiological buffer $(0.1 \mathrm{M}$ phosphate, $4 \mathrm{mM} \mathrm{NaCl}$, $\mathrm{pH}$ 7.4) at $\mathrm{t}=0(\mathrm{~A})$ and $\mathrm{t}=18 \mathrm{~h}(\mathrm{~B})$

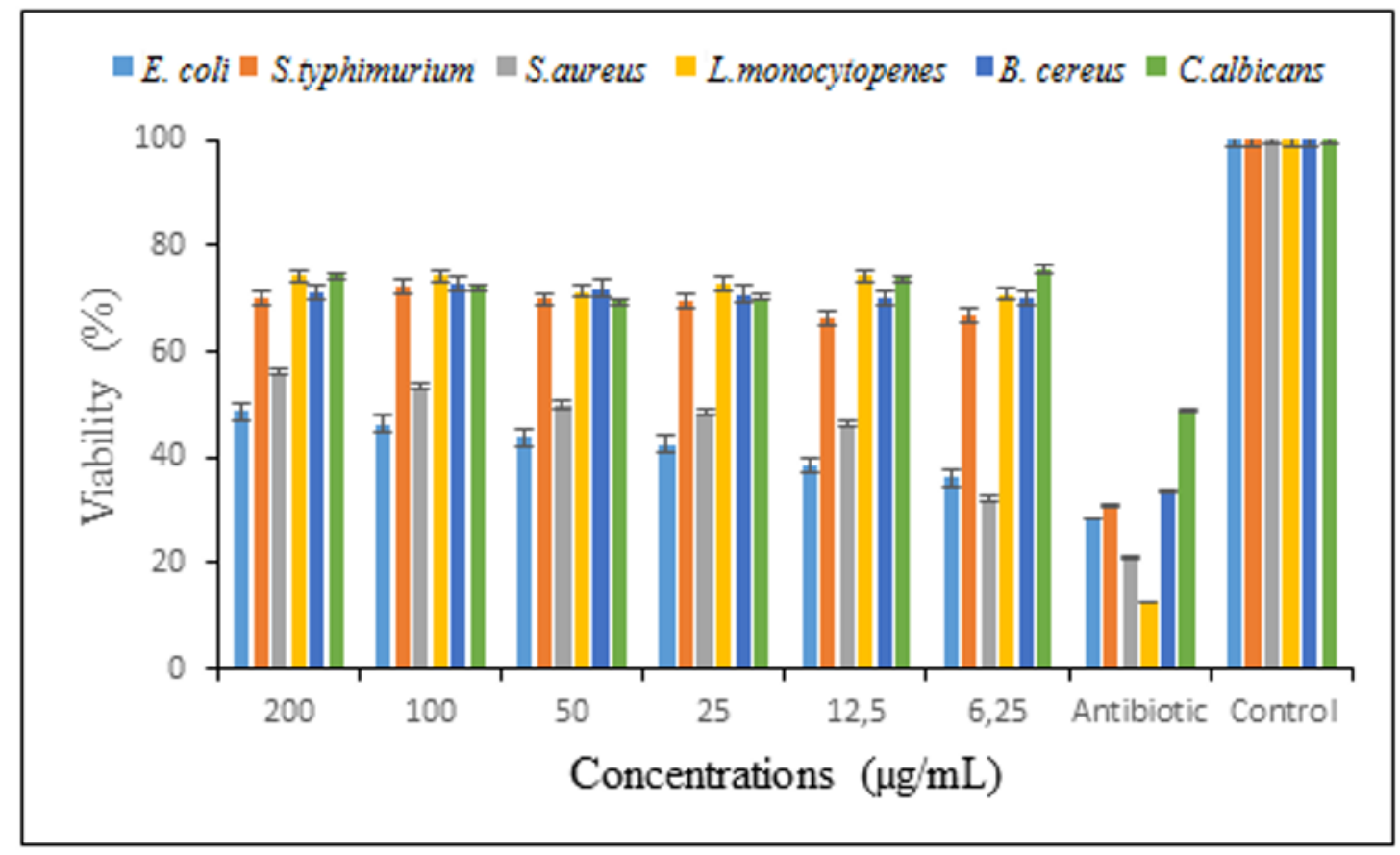

(a)

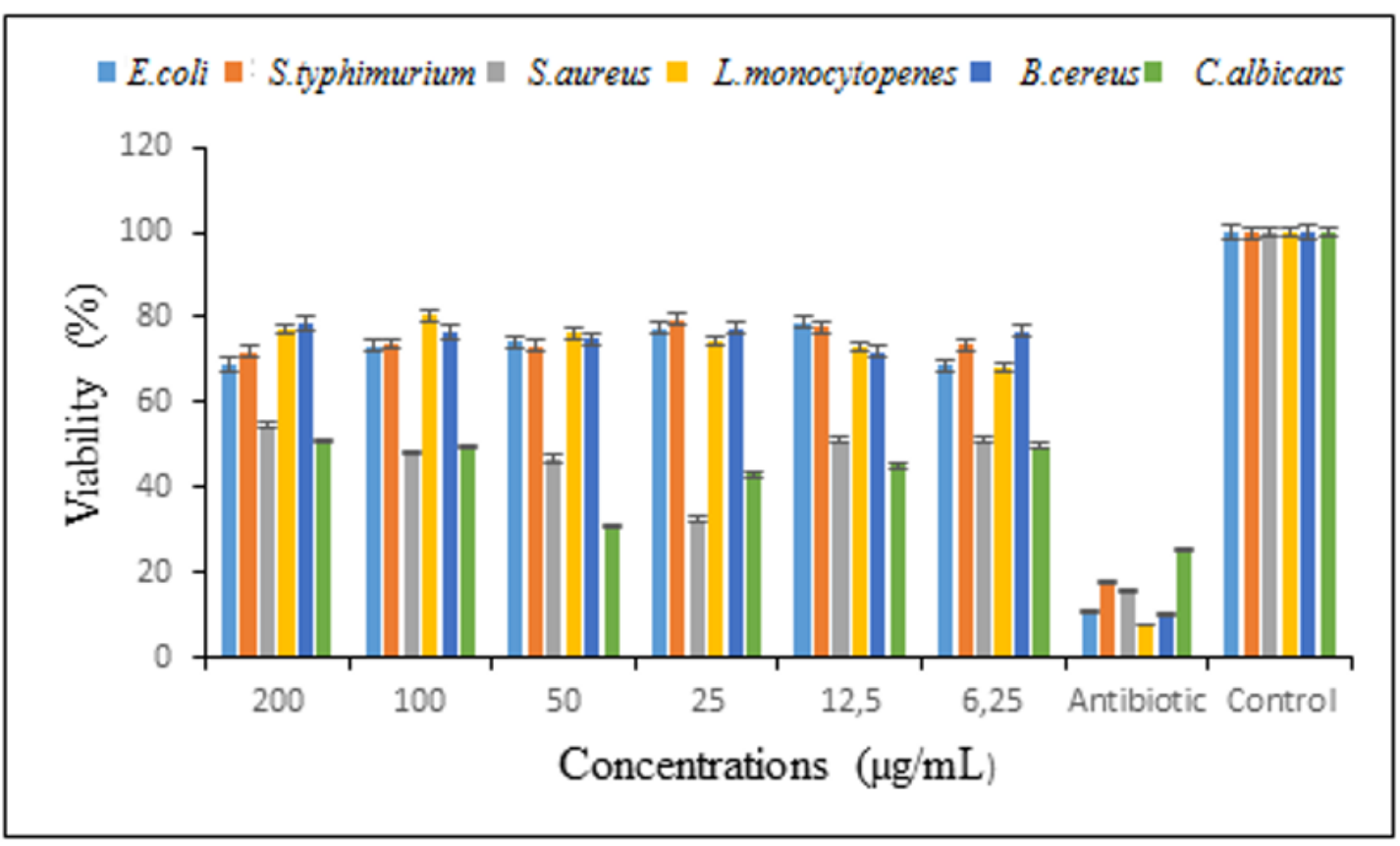

(b)

Figure 3

The viability (\%) values of E. coli, S. typhimurium, S. aureus, L. monocytogenes, B. cereus and C. Albicans for the BBHMP (a) and Pt(II) complex (b) at different concentration $(200-6.25 \mu \mathrm{g} / \mathrm{ml}) .(\mathrm{n}=4) \pm$ S.E. 


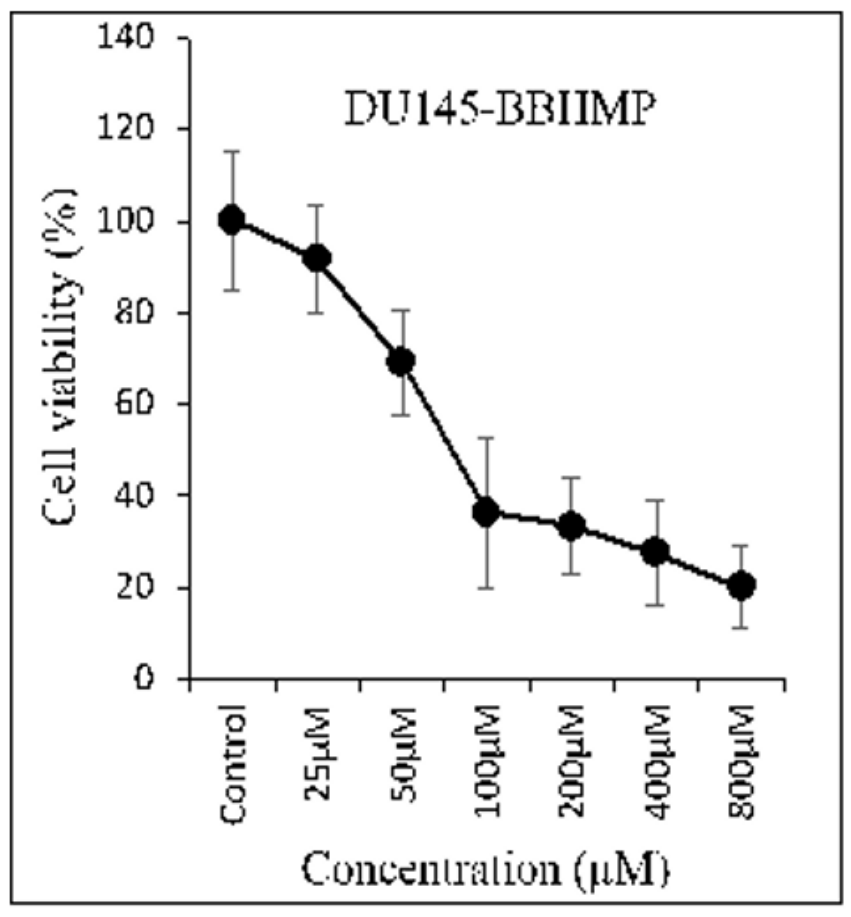

(a)

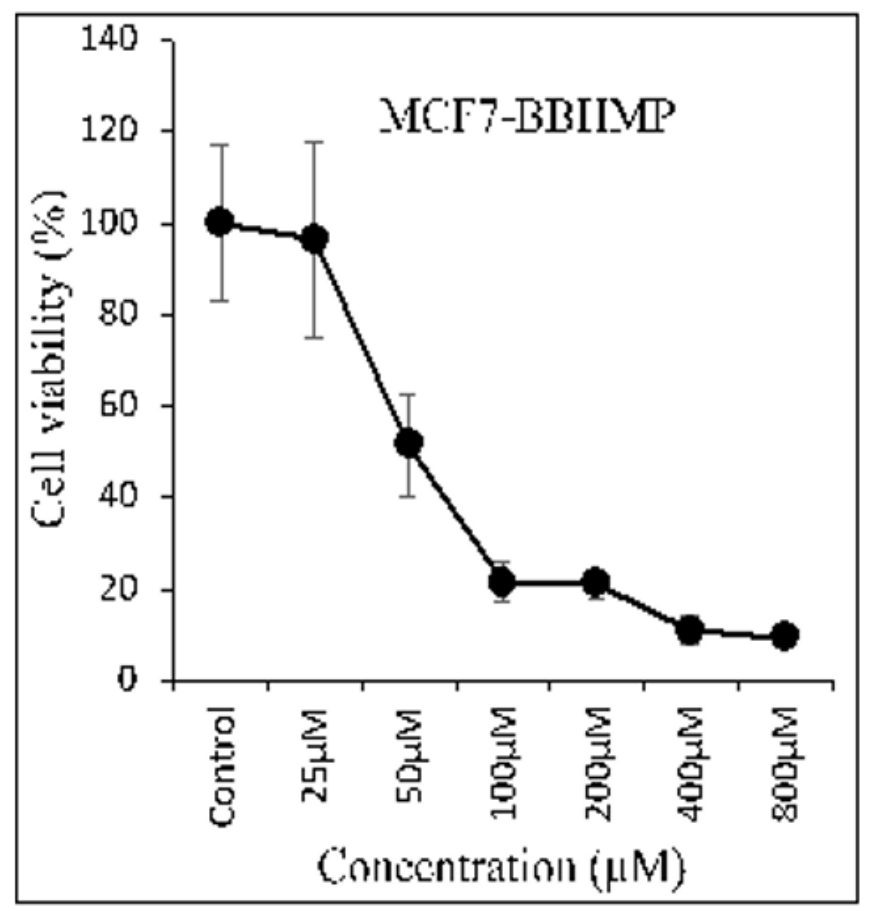

(c)

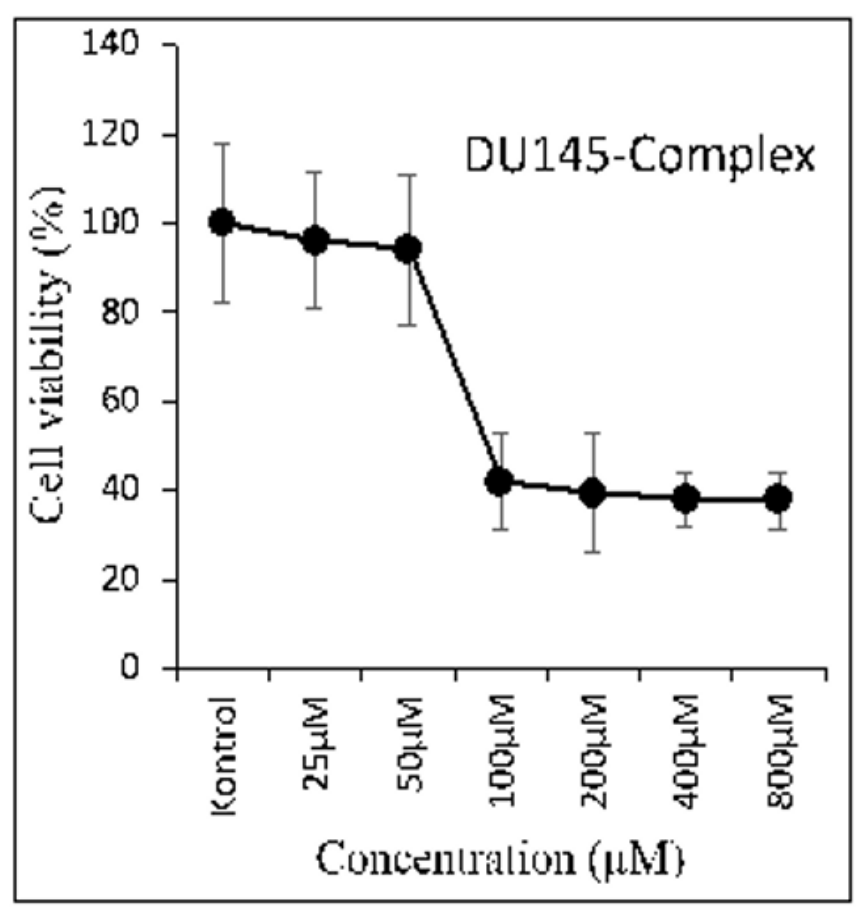

(b)

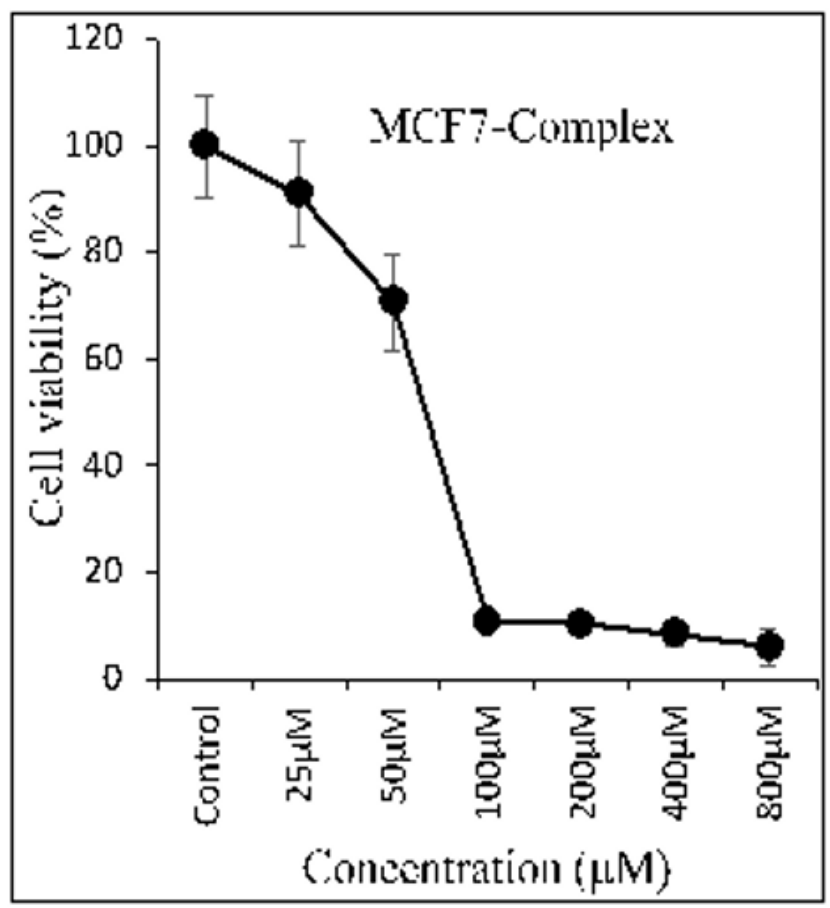

(d)

\section{Figure 4}

Cell viability (\%) in DU145 and MCF7 cell treated with six different doses of the BBHMP or Pt(II) complex for 24 hours. All values are presented as the mean values of percentages for each group $(n=6) \pm S E$. The probit analysis was performed to calculate IC50 values and MTT values at 24 hours were used for this. 


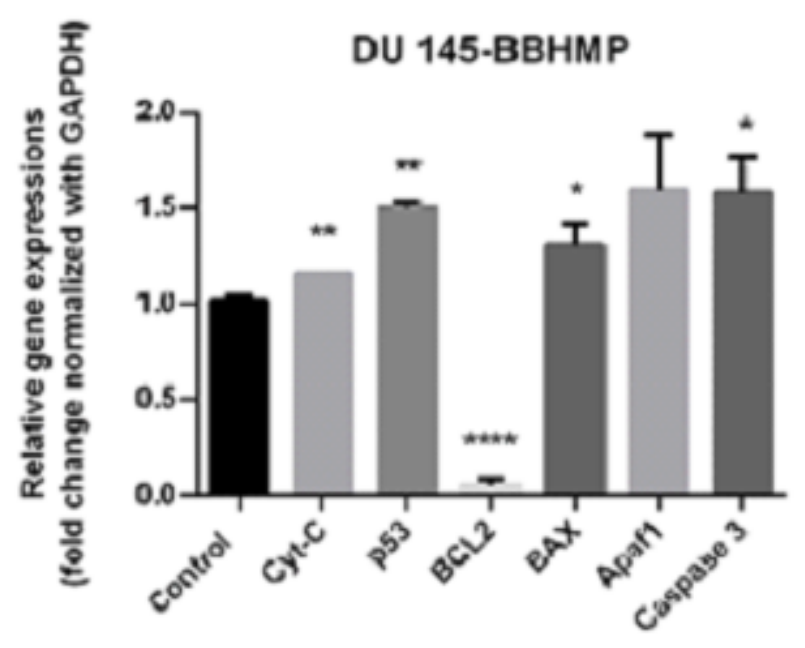

(a)

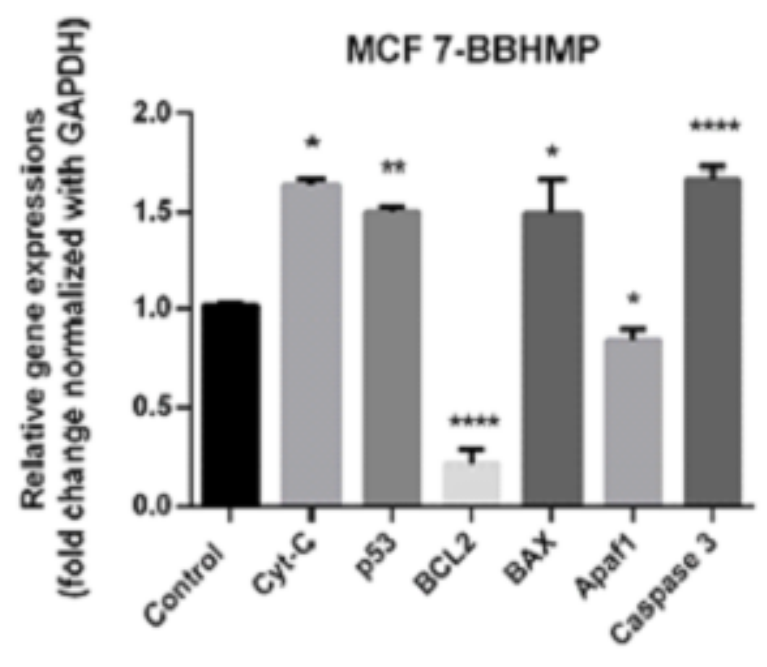

(c)

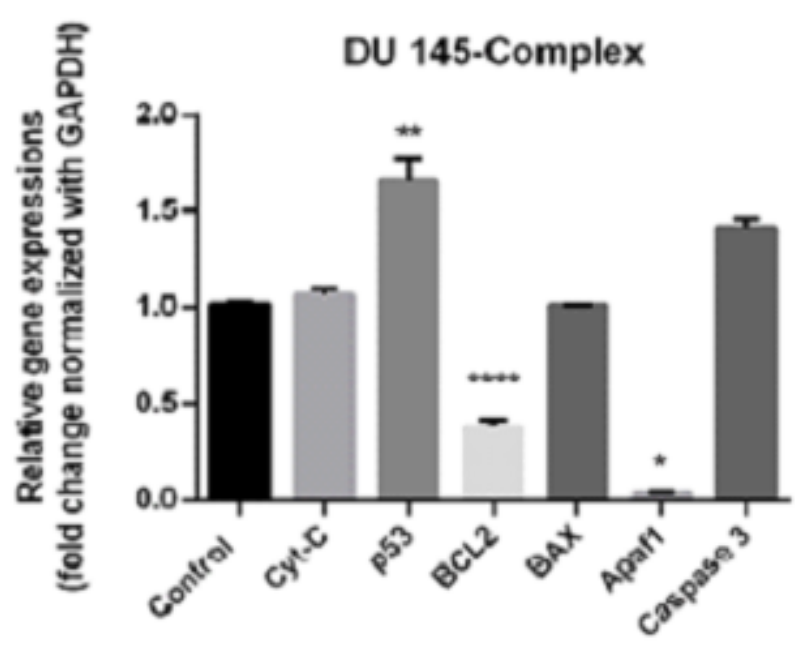

(b)

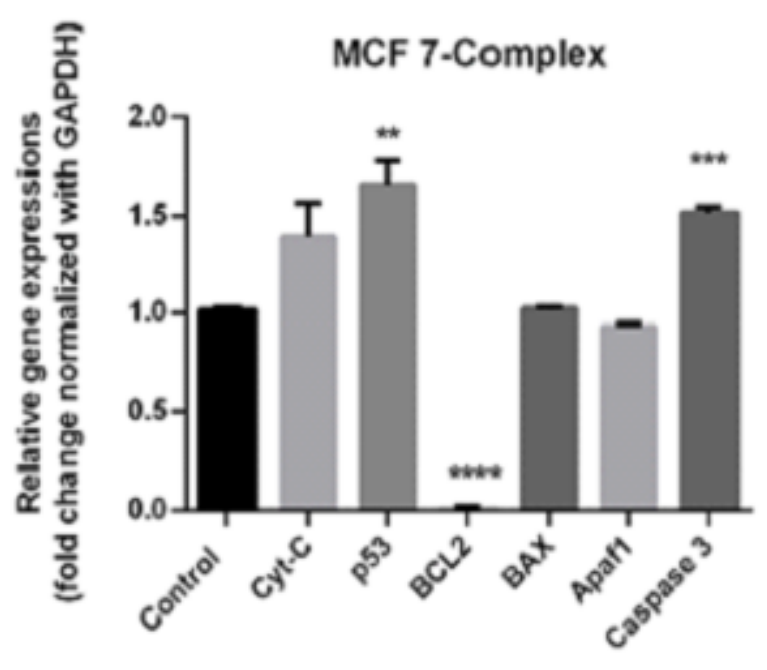

(d)

\section{Figure 5}

Relative fold change recorded with quantitative real-time PCR (qRT-PCR) analysis of apoptosis pathway genes in vehicle treated control and BBHMP or Pt(II) complex exposed DU145 and MCF7 cell lines. All values were normalised with GAPDH expression and presented as relative to control; $(n=4) \pm S E . *(p \otimes$ $0.05), * \star(p \otimes 0.01), * \star \star(p \otimes 0.001), * \star \star \star(p \otimes 0.0001)$, analysed by one-way ANOVA, post hoc Tukey test. 


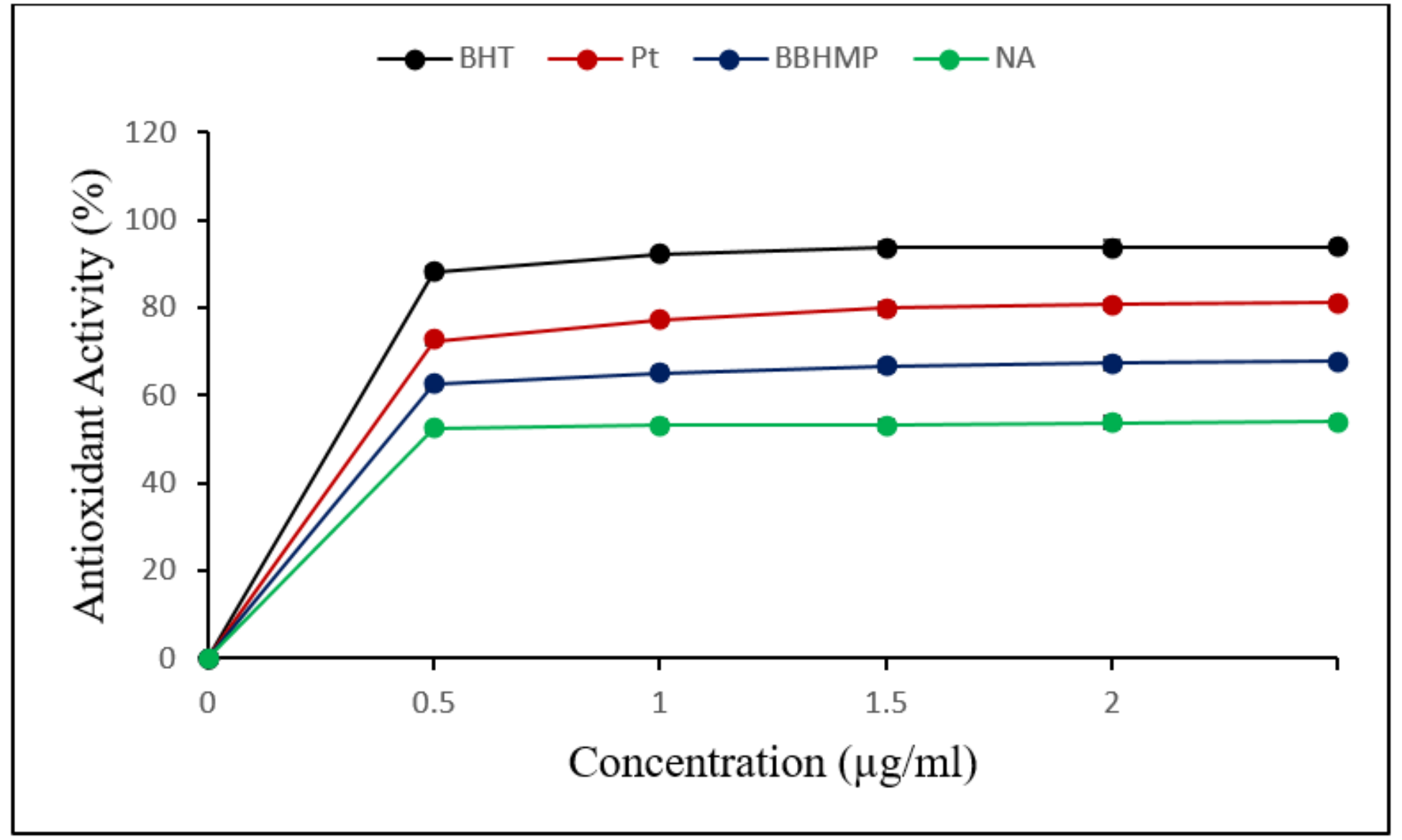

Figure 6

Percent antioxidant activity of the BBHMP, NA and Pt(II) complex at room temperature. $(n=2) \pm$ S.E.

\section{Supplementary Files}

This is a list of supplementary files associated with this preprint. Click to download.

- SupplementaryMaterials.docx 